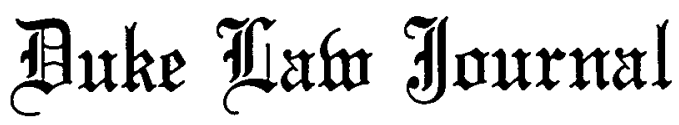

VOLUME 1980

APRIL

NUMBER 2

\section{LABOR-ANTITRUST: THE PROBLEMS OF CONNELL AND A REMEDY THAT FOLLOWS NATURALLY}

\author{
JOSEPH T. CASEY, JR.* \\ and Michael J. Cozzillio**
}

Since the passage of the Sherman Act, ${ }^{1}$ the Supreme Court has struggled to formulate a test governing labor's exemption from the antitrust laws. Resolution of this issue has required the Court to reconcile two competing and at times diametrically opposed congressional directives without subordinating one to the other. ${ }^{2}$ On one hand, the antitrust laws are designed primarily to msure that economic power is diffused among competitors. It is generally believed that the public will benefit, in terms of lower prices and better products, from increased competition in the production and marketing of goods and services and

* B.A. 1973 University of Massachusetts; J.D. 1976 Northwestern University School of Law; Associate, Akin, Gunip, Hauer \& Feld, Washington, D.C.

** B.A. 1970 University of Delaware; J.D. 1973 Catholic University of America School of Law; Partner, Akin, Gump, Hauer \& Feld, Washington, D.C.

The authors thank Stephen B. Goldberg, Visiting Professor, Harvard University Scliool of Law, for his extremely helpful comments and criticisms on earlier drafts of this Article.

THE FOLLOWING CITATION WILL BE USED IN THIS ARTICLE:

Meltzer, Labor Unions, Collective Bargaining and the Antitrust Laws, 32 U. CHl. L. REv. 659 (1965) [heremafter cited as Meltzer].

1. Cl. 647 , $\S \S 1-7,26$ Stat. 209 (current version at 15 U.S.C. $\$ \S 1-7$ (1976)).

2. The Court's attempts at reconciliation have been the subject of incisive academic scrutiny. After careful analysis of the Court's rulings in this area, one commentator concluded that the conflict between antitrust and labor policies was "so irreconcilable that . . . the regulatory distmctions employed must be largely arbitrary-there are no general principles by which these policies can be harmonized." Winter, Collective Bargaining and Competition: The Application of Antitrust Standards to Union Activities, 73 YALE L.J. 14, 16-17 (1963). See also Cox, Labor and the Antitrust Laws-A Preliminary Analysis, 104 U. PA. L. Rev. 252, 254-55 (1955); Meltzer 659; St. Antoine, Connell: Antitrust Law at the Expense of Labor Law, 62 VA. L. Rev. 603 (1976). 
from decreased concentration of capital and other economic resources. ${ }^{3}$ The federal labor laws, on the other hand, encourage economic concentration by recognizing and protectimg the rights of employees to organize within appropriate units and to bargam collectively regarding their wages, hours, and other working conditions. ${ }^{4}$ The principal theory underlying the labor laws, as embodied in the National Labor Relations Act, ${ }^{5}$ is that peaceful settlement of labor-management disputes can be achieved through the mediatory influence of collective bargaining. ${ }^{6}$

Friction develops between these two pohcies where, for example, a union attempts to organize along a particular service or product line. If successful, the union creates a sizeable pocket of economic concentration, eliminatimg competition among its employers in one substantial component of production costs-the price of labor. ${ }^{7}$ Further, direct market restraimts often result from collective bargaining agreements designed to protect union members' wages or other working conditions. An agreement that requires an employer to refram from dealing with nonunion companies paymg a lower wage scale may insure better wages and job security, but the resulting restramts on the product market cannot otherwise be justified under section 1 of, the Shernan Act. ${ }^{8}$

The Supreme Court's most recent pronouncement on this sensitive issue involved a union's efforts to organize the employees of mechanical subcontractors in the Dallas, Texas area. In Connell Construction Co. v. Plumbers Local 100,9 the Court ruled in a 5-4 decision that a union forfeits its exemption from the antitrust laws where it seeks to impose direct market restraimts through an agreement with a nonlabor

3. See, e.g., Northern Pac. Ry. v. United States, 356 U.S. 1, 4 (1958). See generally 1 P. AREeda \& D. TURNER, ANTITRUST LAW 17-18 (1978).

4. See, e.g., NLRB v. American Nat'l Ins. Co., 343 U.S. 395 (1952). See generally Cox \& Dunlop, Regulation of Collective Bargaining by the National Labor Relations Board, 63 HARv. L. REv. 389 (1950).

5. 29 U.S.C. $\$ \S 141-187$ (1976).

6. See Fibreboard Paper Prods. Corp. v. NLRB, 379 U.S. 203, 211 (1964). In the Wagner Act, 29 U.S.C. $\S \S 151-158,159-166$ (1976), Congress declared that "[e]xperience has proved that protection by law of the right of eniployees to organize and bargain collectively safeguards commerce from injury, impairment, or niterruption, and promotes the flow of commerce by renoving certain recognized sources of imdustrial strife and unrest . . . "Id. \$ 151 .

7. Under traditional antitrust notions, an agreement fixing such a signiflcant element of the final price would constitute a per se antitrust offense. United States v. Socony-Vacuuin Oil Co., 310 U.S. 150 (1940); National Macaroni Mfrs. Ass'n v. FTC, 345 F.2d 42I (7th Cir. 1965); see Di Cola, Labor Antitust: Pennington, Jewel Tea and Subsequent Meandering, 33 U. PITT. L. Rev. 705, 706-07 (1972).

8. 15 U.S.C. $\$ 1$ (1976); see, e.g., Klor's, Inc. v. Broadway-Hale Stores, Inc., 359 U.S. 207 (1959). See also Leslie, Right to Control: A Study in Secondary Boycotts and Labor Antitrust, 89 HARv. L. Rev. 904, 914-18 (1976); Note, Boycott: A Specific Definition Limits the Applicability of a Per Se Rule, 71 Nw. U.L. Rev. 818, 822-23 (1977).

9. 421 U.S. 616 (1975). 
party outside the collective bargaining context, with resultant anticompetitive effects that do not "follow naturally from the elimination of competition over wages and working conditions." 10 Although the Connell holding seems to be straightforward, its application has generated a great deal of academic criticisin ${ }^{11}$ and robust judicial debate. ${ }^{12}$ Most of this controversy relates to two legal issues: first, the degree, if any, to which comphance with the labor laws affects or controls the availability of the labor exemption; and second, if no exeinption is found, whether traditional principles of antitrust law, such as the per se rule of illegality, should be applied to the labor conduct in question.

The purpose of this Article is to demonstrate that the Connell approach cannot provide satisfactory answers to these two questions. The analysis begins with a brief discussion of pertinent pre-Connell cases im Part I and proceeds to a critique of the Connell decision in Part II, with special attention given to the Court's newly created "follow naturally" test. In Part III we examine the lower court decisions im which the Connell test has been apphied, and we conclude that Connell provides inadequate guidance on the scope of the labor exemption and on the correct apphication of antitrust principles to nonexeinpt conduct. In Part IV we suggest a more practical approach that would eliminate the ambiguities of the Connell decision on both of these issues.

\section{BACKGROUND OF THE LABOR EXEMPTION}

Although there were serious doubts whether Congress originally intended the Shernan Act to apply to union conduct at all, ${ }^{13}$ the courts,

10. Id. at 625 .

11. See, e.g., Monaghan, The Supreme Court, 1974 Term, 89 HARv. L. REv. 1, 234-45 (1975); St. Antoine, supra note 2; Note, Antitrust Liability of Labor Unions, 17 B.C. INDUS. AND CoM. L. REv. 217 (1976); Comment, Connell: Broadening Labor's Antitrust Liability While Narrowing its Construction Industry Proviso Protection, 27 CATH. U.L. REv. 305 (1978). While there is considerable disagreement about the interpretation and potential impact of Connell, there appears to be unanimity regarding its failure to provide any meaningful guidance to the lower courts: "In evaluating Connell's new consensus, the result reached by the majority can be viewed as another sui generis response to a particular problem in a specific industry rather than the exposition of a governing principle that might guide lower courts and litigants in future cases." F. BARTosic \& R. Hartley, Labor Relations Law in the Private Sector 190 (1977).

12. See notes $120-80$ infra and accoinpanying text for an analysis of the conflicting lower court opinions arising from the Connell holding. One district court openly questioned the wisdom of the Court's Connell holding, which allows union conduct that is unlawful under the labor laws to be subject to antitrust attack as well. See Signatory Negotiating Comm. v. Local 9, Int'I Union of Operating Eng'rs, 447 F. Supp. 1384, 1390 (D. Colo. 1978).

13. See, e.g., E. BERMAN, LABOR AND THE ShERMAN ACt (1930). "It thus appears that the courts, in deciding that Congress intended that the Anti-trust Law should reach labor unions, came to a conclusion which cannot be supported by a careful and thoroughgoing examination of 
beginning principally with Loewe v. Lawlor (Danbury Hatters) ${ }^{14}$ in 1908 and continuing until the passage of the Wagner Act ${ }^{15}$ and the Norris-LaGuardia Act ${ }^{16}$ in the 1930 s, consistently found union-induced strikes, ${ }^{17}$ secondary boycotts and picketing, ${ }^{18}$ and other union activities ${ }^{19}$ to be antitrust violations. To reach these results, the courts apphed an "objectives test," which allowed the courts to determine the lawfulness of the unions' conduct on the basis of the propriety of their immediate goals. ${ }^{20}$ After the enactment of the Norris-LaGuardia Act and the Wagner Act, the Court reevaluated its antitrust-labor analysis in four decisions that forined the general framework for labor's immunity during the two decades that followed.

the most substantial evidence available, the Congressional Record." Id. 53. See also St. Antoine, supra note 2, at 604 \& n.7.

Congress, however, has always been reluctant to define the proper bounds of the labor exemption, and where it has acted, its pronouncements have been ambiguous. Congress first sought to extricate union activities from the antitrust laws by enacting the Clayton Act im 1914 to provide that the "labor of a human being [was] not a commodity or article of commerce," and that certain union activities such as strikes and boycotts were not antitrust violations. Clayton Act, ch. 323, $\S \S 6,20,38$ Stat. 730 (1914) (current version at 15 U.S.C. $\S 17$ (1976), 29 U.S.C. § 52 (1976)). Although the Clayton Act was initially hailed as "the foundation upon which the workers can establish greater liberty," 51 CONG. REC. 16,340 (1914) (remarks of Rep. Buchanan), the euphoria was short-hived. The courts narrowly construed the terms "lawfully" and "legitimate" in the Act as a congressional reaffirmation and codification of prior rulings striking down union activities as restraints of trade. For a discussion of these cases, see United States v. Hutcheson, 312 U.S. 219, 235-36 (1941); Winter, supra note 2, at 32-38.

The courts' narrow construction of the Clayton Act later prompted Congress to enact the Norris-LaGuardia Act, ch. 90, 47 Stat. 70 (1935) (current version at 29 U.S.C. $\$ \$ 101-115$ (1976)), which was imtended to deprive federal district courts of jurisdiction to issue mjunctions im cases "mvolving or growing out of a labor dispute," with certain limited exceptions. 29 U.S.C. $\S \S 101$, 104, 107, 113 (1976). Although the Hutcheson Court used the Norris-LaGuardia Act, coupled with a reexamination of the Clayton Act, to shield most forms of unilateral union conduct, the courts continued to apply the antitrust laws to union activities, prompting commentators to urge Congress to act again. See Cox, supra note 2, at 283-84; Meltzer 704-06; Comment, Labor's Antitrust Exemption after Pennington and Jewel Tea, 66 ColuM. L. Rev. 742, 762-63 (1966). Congress has remained silent, however, except to declare certain secondary activities to be unfair labor practices under the NLRA. Landrum-Griffin Act, Pub. L. No. 86-257, 73 Stat. 519 (1959) (current version at 29 U.S.C. § 158(e) (1976)); Taft-Hartley Act, ch. 120, 61 Stat. 136 (1947) (current version at 29 U.S.C. § 158(b)(4) (1976)).

14. 208 U.S. 274 (1908).

15. Ch. 372,49 Stat. 449 (1935) (current version at 29 U.S.C. $\S \S 151-158,159-166$ (1976)).

16. Ch. 90,47 Stat. 70 (1932) (current version at 29 U.S.C. $\$ \S 101-115$ (1976)).

17. United Mme Workers v. Coronado Coal Co., 259 U.S. 344 (1922); Alco-Zander Co. v. Amalgamated Clothing Workers, 35 F.2d 203 (E.D. Pa. 1929).

18. Bedford Cut Stone Co. v. Journeymen Stone Cutters Ass'n, 274 U.S. 37 (1927); United States v. Brims, 272 U.S. 549 (1926).

19. Williams v. United States, 295 F. 302 (5th Cir. 1923) (sabotaging locomotive engines), cert. denied, 265 U.S. 591 (1924).

20. Cox, supra note 2, at 269. See generally Cox, The Role of Law in Labor Disputes, 39 CORNELL L.Q. 592 (1954). 
The first case of this quartet, Apex Hosiery Co. v. Leader, ${ }^{21}$ involved the application of the Sherman Act to a violent sitdown strike conducted by a union to obtain a closed shop agreeinent froin its einployer. Because the einployer's goods in Apex Hosiery were effectively prevented from entermg interstate commerce, the labor activities involved in Apex undoubtedly would have constituted an antitrust violation under prior case law. ${ }^{22}$ After an exhaustive review of this case law, however, the Court chose to direct its antitrust approach away froin a literal reading of "restraint of trade" 23 and to focus instead on the impact of the union activity in the commercial market. Under this analysis, the Court held the strike exempt from antitrust prosecution, concluding that "some form of restraint of commercial competition has been the sine qua non to the condemnation of contracts, combinations, or conspiracies under the Sherman Act, and in general restraints upon, competition have been condemned only when their purpose or effect was to raise or fix the market price." 24 This ruling formed the basis for the Court's dictun that "elimination of price coinpetition based on differences in labor standards . . . has not been considered to be the kind of curtailment of price competition prohibited by the Sherman Act."25

Although one step reinoved froun prior case law holding that virtually all interferences with interstate commerce were unlawful restraints of trade, the Apex Hosiery ruling was still based solely on antitrust considerations. ${ }^{26}$ The Court did not directly address the applicability of the Wagner and Norris-LaGuardia Acts in determining the labor exemption issue. Those statutes, however, were destined to assume a more promment role in determining labor's antitrust exposure in the second of the four cases, United States $\nu$. Hutcheson. ${ }^{27}$

In Hutcheson the Court considered the lawfulness of a union's sec-

21. 310 U.S. 469 (1940).

22. Id. at 483.

23. See 15 U.S.C. \& 1 (1976).

24. 310 U.S. at 500 (footnote omitted).

25. Id. at 503-04.

26. Because the issue was not briefed, the Court declined to consider whether the rule of reason as announced in Standard Oil Co. v. United States, 221 U.S. 1 (1911), was applicable to the union's conduct. 310 U.S. at 507 n.25.

27. 312 U.S. 219 (1941). Hutcheson was one of five criminal and civil suits brought by the United States Attorney General against unions about this time. See United States v. American Fed'n of Musicians, 318 U.S. 741 (1943) (per curiam); United States v. Building \& Constr. Trades Council, 313 U.S. 539 (1941) (per curian1); United States v. United Blid. of Carpenters \& Joiners, 313 U.S. 539 (1941) (per curiam); United States v. Internatioual Hod Carriers \& Common Laborers' Dist. Council, 313 U.S. 539 (1941) (per curiam). These prosecutions are noteworthy because they illustrate the Justice Department's ad hoc judgment regarding the undesirability of the unions' couduct, notwithstanding the legislative intent of the Norris-LaGuardia Act. Winter, supra note 2 , at 44 . 
ondary boycott and picketing in a dispute over work jurisdiction. ${ }^{28}$ The Court easily could have applied the Apex Hosiery "commercial inarket" doctrine to dispose of the antitrust allegations, but it opted instead to read the Sherinan, ${ }^{29}$ Clayton, ${ }^{30}$ and Norris-LaGuardia Acts ${ }^{31}$ together as a "harınonizing text of outlawry of labor conduct." 32 In holding that the union's activities were protected under section 20 of the Clayton Act, ${ }^{33}$ the Court set a standard that would shield almost every forin of unilateral union activity. Justice Frankfurter, speaking for the court, stated:

So long as a union acts in its self-interest and does not combine with non-labor groups, . . . the licit and the illicit . . . are not to be distinguished by any judgment regarding the wisdom or unwisdom, the rightness or wrongness, the selfishness or unselfishness of the end of which the particular union activities are the means. ${ }^{34}$

With this language, the Court apparently signalled an end to an objectives test and substituted a two-part approach allowing the exemption where the labor union acts in its self-interest and does not combine with nonlabor groups.

The Court's analysis in Hutcheson left open the possibility that union activity carried out in counbination with nonlabor groups could be exeenpt in soine circumstances. The Court dealt with this possibility four years later when it decided the two remaining cases of the quartet, Allen Bradley v. Local 3, International Brotherhood of Electrical Workers ${ }^{35}$ and Hunt v. Crumboch. ${ }^{36}$

In Allen Bradley the Supreme Court was faced with an ingenious and highly successful scheme in which New York City electrical contractors agreed to purchase their equipinent exclusively from those inanufacturers having a collective bargaining agreeinent with the union. The manufacturers, in turn, agreed to sell only to those contractors employing the union's nembers, and the union vigorously enforced the agreenents by striking or boycotting offenders. ${ }^{37}$ Gradually, this scheine expanded and gave way to price fixing, market control, and

28. 312 U.S. at $227-28$.

29. 15 U.S.C. $\S \S 1-7$ (1976).

30. 29 U.S.C. $\$ 52(1976)$.

31. Id. $\$ \$ 101-115$.

32. 312 U.S. at 231.

33. 29 U.S.C. $\$ 52(1976)$.

34. 312 U.S. at 232 (footnote omitted).

35. 325 U.S. 797 (1945).

36. 325 U.S. 821 (1945).

37. 325 U.S. at 799. Such contracts are commonly referred to as "hot-cargo" agreements. Subsequent to the Allen Bradley decision, Congress amended the National Labor Relations Act to prohibit certain types of hot-cargo agrcements and umion activity undertaken to mduce the signing of or to enforce such agreements. Landrum-Griffin Act, Pub. L. No. 86-257, 73 Stat. 519 (1959) 


\section{bid rigging. ${ }^{38}$}

The Court defined the issue in Allen Bradley narrowly: did the "Tabor unions violate the Sherman Act when, in order to further their own interests as wage earners, they [aided] and [abetted] business men to do the precise things which [the] Act prohibits?"39 After finding that the conspirators had achieved a virtual monopoly over a segment of the industry in New York City, the Court held the labor exemption unavailable. Despite this holding, however, the majority assumed that the union agreenients with the manufacturers and contractors, absent price fixing, market control, and bid rigging, would have been exeinpt. ${ }^{40}$

This interpretation of the labor exemption was confirmed in the Hunt opinion, rendered the sanie day. The union in Hunt had been able to force a freight carrier out of busmess by signing and enforcing closed-shop agreements with the carrier's primcipal sources of hauling work and then refusing to negotiate with the carrier or to adinit its employees to membership. As a result, the signatories of the closedshop agreements cancelled their contracts with the carrier. It appears that the sole reason for the union's refusal to deal was its behef that one of the carrier's employees had inurdered a union inember. ${ }^{41}$

The Court held, over a vigorous dissent, ${ }^{42}$ that the union conduct

(current version at 29 U.S.C. \& 158(e) (1976)); Taft-Hartley Act, ch. 120, 61 Stat. 136 (1947) (current version at 29 U.S.C. $\& 158(b)(4)(1976))$.

38. 325 U.S. at 799-800. See generally Bernhardt, The Allen Bradley Doctrine: An Accommodation of Conficting Policies, 110 U. PA. L. Rev. 1094, 1096-97 (1962).

39. 325 U.S. at 801 . Framing the issue in this manner was odd because the monopoly was created exclusively by the IBEW. The employers engaged in price fixing and market control only after the monopoly was formed. See Meltzer 670 n.45. Indeed, it appears from the Second Circuit's opinion in Allen Bradley that the IBEW refrained from "aiding and abetting" and may have disapproved of the contractors' price-fixing scheme. 145 F.2d 215, 218 (2d Cir.), rev'd, 325 U.S. 797 (1945).

40. Justice Black commented that "had there been no union-contractor-manufacturer combination the Union's actions here . . would not have been violations of the Sherman Act." 325 U.S. at 807; see id. at 809, 810. But see Bernhardt, supra note 38, at 1099 (the Court took a "most extreme pro-umion position . . . [which] ignores the facts of the Allen Bradley case").

41. 325 U.S. at 824 .

42. Justice Roberts dissented on the ground that the underlying dispute in Hunt was not a "labor dispute," but rather an "off-shoot" of one, and that the union's conduct amounted to taking. part in a conspiracy to drive a competitor out of business. Id. at 826-28 (Roberts, J., dissenting). Accordingly, he would have ruled that the labor exemption was inapplicable and that the union's activities violated the Sherman Act. Id. at 828.

Justice Jackson, in a longer dissent, also relied on the union's "purpose" in holding that the union's activities in Hunt did not fall within the protection of the Clayton and Norris-LaGuardia Acts. Id. at 828 (Jackson, J., dissenting). He distinguished between strikes designed to compel employers to yield to union demands, which did not coine within the antitrust laws, and umion activities adversely affecting employers after they had acceded to union demands, which could run afoul of the antitrust laws. Id. at 831. In this context, Justice Jackson stated that a "umion cannot consistently with the Sherman Act refuse to enjoy the fruits of its victory and deny peace terms to 
was within the exemption. While recognizing that the union was able to effect such a boycott only through closed-shop agreements with third parties, Justice Black, speaking for the majority, found that "[t]he only conibination here . . . was one of workers alone and what they refused to sell [to the freight carrier] was their labor."43 Thus, a common thread through the Hunt and Allen Bradley cases is that a collective bargaining agreement between a union and an einployer, standing alone, is insufficient to form an illegal combimation unless the agreenient is a part of a larger entployer conspiracy mvolving monopolization and price fixing. 44

During the twenty years that followed the Hunt and Allen Bradley decisions, the Supreme Court was rarely called upon to examme the labor exemption question. Where the Court addressed the issue, its holdings were consistent with the general precepts announced in the Apex through Hunt quartet. ${ }^{45}$ Given the substantial growth and sophistication of the labor movement during those two decades, however, it was natural, if not inevitable, that the antitrust focus would eventually shift from labor activities at the factory plant gate where union recognition was achieved to activities at the bargaining table where union gains were pressed. Consequently, the Supreme Court found it necessary to reassess labor's immunity from the antitrust laws in the context of collective bargaining agreements.

Two cases, United Mine Workers v. Pennington ${ }^{46}$ and Local 189, Amalgamated Meat Cutters v. Jewel Tea Co. ${ }^{47}$ were crucial to this reassessment process. In Pennington plamtiffs alleged an illegal conspiracy between the United Mine Workers Union and a number of the larger coal concerns. This charge was based on the union's agreement to impose high wage scales on smaller mining operators through a protective wage clause im a collective bargaining agreement. The alleged purpose

an employer who has unconditionally surrendered." Id. Both Justices were of the view that some form of an "objectives" test was appropriate in determining the exemption issue.

43. Id. at 824. Justice Black thus distinguished Allen Bradley on the ground that the union in Hunt did not aid and abet a combination of business competitors. Interestingly, the Justice placed no significance on the fact that it was only through employer cooperation, in accordance with the union's closed-shop agreements, that Hunt was deprived of work.

44. But see Bernhardt, supro note 38, at 1097-1101 (suggesting that there are at least five different ways of interpreting the Allen Bradley conbination doctrime, each of which has been followed by various lower courts in ostensible harmony).

45. See, e.g., Los Angeles Meat \& Provision Drivers Union v. United States, 371 U.S. 94 (1962); Local 24, Int'l Bhd. of Teamsters v. Oliver, 358 U.S. 283 (1959); United States v. Women's Sportswear Mfrs. Ass'n, 336 U.S. 460 (1949); cf. Marine Cooks \& Stewards v. Panama S.S. Co., 362 U.S. 365 (1960) (Norris-LaGuardia Act deprives federal district court of jurisdiction to enjoin union froin peacefully picketing a foreign ship).

46. 381 U.S. 657 (1965).

47. 381 U.S. $676(1965)$. 
of the conspiracy was to force the small operators out of busimess. ${ }^{48}$ In Jewel Tea, plaintiffs charged that the union had conspired with Jewel Tea's less efficient competitors to restrict the sale of fresh meat after 6:00 p.1n., again through a collective bargaining agreenent. While a clear majority view did not emerge on the exact rule to be applied to the exemption question, the principles offered in these two cases imphed at least a partial retreat froin the doctrines announced in the Apex through Hunt quartet and a return to some form of an objectives test.

Justice White, joined by Chief Justice Warren and Justice Brennan, wrote the opimion of the Court in both cases. In Pennington, the Court held that the union forfeited its exemption because it conspired with a nonlabor group to inpose a market restraint. ${ }^{49}$ There was, to be sure, precedent supporting this ruling. If the allegations in Pennington were true, the United Mine Workers were aiding and abetting an employer conspiracy to interfere with the market. Under this approach, the alleged conspiracy would have been similar to that condemned by the Court in Allen Bradley.

There are, however, two substantial differences between the agreements at issue in Pennington and in Allen Bradley. First, the union in Pennington was participating in the alleged conspiracy through a wage clause-a mandatory subject of collective bargaining, traditionally thought to be exempt under Apex-as opposed to the hot-cargo agreements involved in Allen Bradley. Second, the conduct held unlawful in Allen Bradley was treated as separate from the collective bargaining agreements, ${ }^{50}$ while the conspiracy in Pennington was based directly on such an agreeinent. ${ }^{51}$ On both these points, however, Justice White emphasized that

[u]nilaterally, and without agreement with any employer group to do so, a union may adopt a uniform wage policy and seek vigorously to implement it even though it may suspect that some employers cannot effectively compete if they are required to pay the wage scale demanded by the union. . . . Such union conduct is not alone sufficient evidence to maintaim a union-employer conspiracy charge under the Sherman Act. 52

By this limitation, Justice White was probably attempting to quell any fears that industrywide wage demands alone could become subject to antitrust scrutiny. No such scrutimy would be required, even where the uniform wage demands were "not [geared] ... to wages which the

48. 381 U.S. at $665-66$.

49. Id. at 665 .

50. See text accompanying note 40 supra.

51. See 381 U.S. at 662 .

52. Id. at 665 n.2. 
weakest units in the industry [could] afford to pay." 53

The conspiracy element in Pennington was not the only reason for the United Mine Workers' potential antitrust hability. Justice White also found that the union's breach of its duty to bargam unit-by-unit was in derogation of national labor policy. ${ }^{54} \mathrm{He}$ stated that "[t]he union's obligation to its members would seem best served if the union retamed the ability to respond to eacl bargaining situation . . . without begin straitjacketed by some prior agreement . . . ."5s By interlacing this labor law element with the alleged conspiracy, the Justices were evidently moving toward balancing the objectives of labor and antitrust policy in determining the parameters of the exemption. ${ }^{56}$

In Jewel Tea the same meinbers of the Court again relied on this balancing test and, in so doing, may have created nore confusion than clarity. In essence, they held that even where there is no allegation of conspiracy between a union and a nonlabor group, the union still might forfeit its antitrust immunity if it imposed, through a collective bargaining agreement, a direct restraint that was not "intimately related to" its wages, hours, or other working conditions. ${ }^{57}$ To clarify this standard, they noted that " $[t]$ he crucial determinant is not the form of the agreement-e.g., prices or wages-but its relative mipact on the product inarket and the interests of union menibers." 58 Thus, in theory,

53. Id.

54. Id. at 665-66. Justice White later noted in Pennington that the union's agreement with one group of employers to set uniform labor standards for all employers offended the antitrust laws as well. Id. at 668 . He stated that when a union "surrenders its freedom of action" vis-a-vis other eniployers, it violates the antitrust laws by restricting the "freedom of economic units to act according to their own choice and discretion . . . ." Id.

55. Id. at 666.

56. Although this approach should certainly be considered salutory on its face, one can question the method by which Justice White attempted to balance these policies. His statement that the members of the union would have been better served had the United Mime Workers bargained unit-by-unit implied that the judiciary was empowered and equipped to determime the better approach to be taken in collective bargaining negotiations. Justice White apparently anticipated criticisin along these lines and sought to strengthen his position by referring to a number of $\mathrm{Na}$ tional Labor Relations Board decisions holding that an employer could not condition his signing of a collective bargaining agreement on the union's securing a similar agreement from his competitors. Id. at 666-67. The cases, however, provide only limited support for his view, as they deal with the narrower question of whether an employer can refuse to recognize a union or sign an agreement until the union has organized the employer's competitors. Id. at $725 \mathrm{n.25}$ (Goldberg, J., dissenting). Moreover, as Professor Meltzer has noted, rehance on these cases was also misplaced "because demands that the NLRA forbids . . . may, nevertheless, be . . . voluntarily accepted by the other party, without any violation of that statute." Meltzer 717.

57. 381 U.S. at $689-90$.

58. Id. at 690 n.5. Under this criterion it is difficult if not impossible to view the union's conduct in Hunt as nonexempt. The "relative impact" on the market in Hunt was immediate: a competitor was eliminated from the market entirely. In addition, this restraint was not in any way "intimately related" to the union's wages, hours, or other working conditions. Rather, it was 
they proposed that courts weigh the benefits that the union receives from the specific agreement against the detrimental impact on competition in the marketplace. As this test was applied to the facts in Jewel Tea, however, these Justices considered only the union's interest in the marketing restriction clause and concluded that the union's conduct was exempt. The Court did not determine, or for that matter even discuss in any detail, the impact of the clause on the market.59

Notwithstanding this inconsistency, the more important aspect of the Court's analysis is that Justices White, Warren, and Brennan were willing to allow lower courts to weigh union concerns against resultmg market restraints. This approach, as Professor Cox has aptly noted, would permit the judiciary to "revert to a practice from which they were ousted by the Norris-LaGuardia Act-that of weighing the social desirability or undesirability of the union objectives."60

Justice Douglas, joined by Justices Black and Clark, concurred with the Court's opinion in Pennington but dissented from it in Jewel Tea. The preinise of both of Justice Douglas's opinions was that the Court had a duty to protect the free enterprise system under the antitrust laws "until the Congress delegates to big business and big labor the power to remold [the] economy"61 through the nredium of collective bargaining agreements. In Pennington Douglas, Black, and Clark interpreted the opimion of the Court to hold that an industrywide collective bargaining agreement, which fixed a wage scale above the financial ability of the smaller competitors, was prima facie evidence of an illegal antitrust conspiracy. ${ }^{62}$ In Jewel Tea, however, they argued that no exemption should be allowed to the union because there was "nothing procompetitive" about the marketing hours restriction. ${ }^{63}$ Thus, these menibers of the Court were inclined to read the Allen Bradley doctrine as encompassing all union activities that resulted in a inar-

related to the umions' vengeance against Hunt for the death of one of its members. See text accompanying note 41 supra.

59. Justice White found that the effect of the marketing hours restriction was apparent and real and that it was an obvious restraint on the product market, 381 U.S. at 691-92, but these findings stand in sharp contrast to the analysis of the anticompetitive effects considered in $P e n$ nington. Furthermore, no consideration was given to the most favored nations clause contained in the Jewel Tea collective bargaining agreeinent. See Jewel Tea Co. v. Local 189, Amalgaunated Meat Cutters, 215 F. Supp. 839, 842 (N.D. Ill. 1963). It may be, as the Court found, that there was no conspiracy between the unions and the smaller grocery stores, but this clause could have been viewed as creating a sheltered market for those stores that would not market fresh meats after 6:00 p.m. without the services of union butchers.

60. Cox, Labor and the Antitrust Laws: Pennington and Jewel Tea, 46 B.U.L. Rev. 317, 326 (1966).

61. 381 U.S. at 675 (Douglas, J., concurring).

62. Id. at 673 (Douglas, J., concurring).

63. 381 U.S. at 736 (Douglas, J., dissenting). 
ket restraint, regardless of whether the restraint was imposed directly or indirectly and whether it was induced by the employer or by the union. Such an approach, although apparently sound in terms of antitrust analysis, clearly ignores the recognized and congressionally accepted anticompetitive nature of labor unions in general and the unique characteristics of collective bargaining in particular.

While Justice Douglas's opimions fashioned the labor exemption principle solely on antitrust concepts, the remaining members of the Court-Justices Goldberg, Harlan, and Stewart-based their opinions more on labor policy and congressional intent. The nub of their reasoning in both cases was that activities concerning mandatory subjects of collective bargaining sliould be beyond the reach of the Sherman Act. ${ }^{64}$ With this rule, they argued, the Court would encourage free and fruitful collective bargaining, while at the same time extracting itself from the process of determining "what public policy in regard to the industrial struggle demands." 65 They severely criticized Justice White's balancing forinula as "a throwback to past days" 66 when courts answered the question of labor's status under the antitrust laws on the basis of what was "socially or economically objectionable."67 Under their approach, they would have held exempt the union activities in both Jewel Tea and Pennington without examining the unions' aims or the resulting effects on the markets. Although their approach suffers froin a rather elementary problein-defining niandatory subjects of collective bargaining for the purpose of antitrust litigation -it is a consistent rationale that accurately reflects the legislative and judicial complexities associated with the exenuption question. ${ }^{68}$

It is virtually impossible to glean one intellectually consistent rule on the labor exemption from the Court's disparate handling of the Pennington and Jewel Tea cases. Justices White, Warren, and Breman appeared willing to adopt a balancing test that would allow weighing the union's interests and methods against the resultant harm to competition in the product inarket. The test proposed in the Goldberg opmion, however, differed substantially from White's approach in the weight accorded to labor concerns: the White group required that the union demand be unilateral and intimately related to union objectives, while the Goldberg group required that the union demand be a

64. Id. at 710 (Goldberg, J., concurring).

65. Id. (Goldberg, J., concurring) (quoting Duplex Co. v. Deering, 254 U.S. 443, 485 (1921) (Brandeis, J., dissenting)).

66. 381 U.S. at 700 (Goldberg, J., concurring).

67. Id.

68. See Handler, Labor and Antitrust: A Bit of History, 40 ANTITRust L.J. 233, 238 (1971). But see Meltzer 730-32; Comment, supra note 13, at 761-62. 
mandatory subject of collective bargaining.

In 1975 the Supreme Court was called upon to determine which approach should control labor's hability under the antitrust laws. The Court's opinion in Connell Construction Co. v. Plumbers Local 10069 tipped the scale decidedly in favor of the White group's balancing approach. An analysis of the case, however, strongly suggests that the Court abandoned the "intimately related" test embodied in Justice White's Jewel Tea opinion and replaced it with a nore rigorous test focusing on the anticompetitive consequences of union activity and leaving the legitimacy of union concerns as an afterthought.

\section{The Connell Case}

The question before the Court in Connell was whether the activities of the Plumbers and Steamfitters Local Union No. $100 \mathrm{im}$ securing and enforcing a hot-cargo agreement with a general construction contractor were exeinpt froin the Sherman Act. ${ }^{70}$ The hot-cargo provision in the disputed contract directed the contractor, Connell, to subcontract specific work "only to firms that are parties to an executed, current collective bargaining agreement"71 with the union. Connell, which had previously subcontracted work to both union and nonunion firms on the basis of competitive bids, refused to sign the agreement. Local 100 responded by stationing a single picket at one of Connell's construction sites. As a result of this activity, all work was halted. The union adinit-

69. 421 U.S. 616 (1975).

70. This dispute appeared to be just one battle of a larger war being waged between the construction trade unions and general contractors in the Dallas, Texas area. The Dallas Building and Construction Trades Council had been attenipting to secure similar hot-cargo agreements from the general contractors in Dallas since at least 1966. These activities were examined by the District of Columbia Circuit in Dallas Bldg. \& Constr. Trades Council v. NLRB, 396 F.2d 677 (D.C. Cir. 1968), and were held violative of section $8(b)(7)(A)$ of the NLRA, 29 U.S.C. $\S$ 158(b)(7)(A) (1976), which prohibits picketing an employer to conpel recognition of a labor organization in locations where another union is already lawfully recognized. The Council then attempted to secure hot-cargo agreements froin general contractors who had no enuployees of their own in an effort to avoid the recognitional problems of section $8(\mathrm{~b})(7)(\mathrm{A})$. These general contractors sought rehef froin the NLRB. Their petitions to the NLRB failed, however, because the General Counsel of the NLRB declined to review a regional office's refusal to issue a complaint. See Connell Constr. Co. v. Plumbers Local 100, 483 F.2d 1154, 1157-58 (5th Cir. 1973), rev'd, 421 U.S. 616 (1975).

71. The specific clause at issue provided:

THEREFORE, the contractor and the union nutually agree with respect to work falling within the scope of this agreement that is to be done at the site of construction, alteration, painting or repair of any building, structure, or other works, that [if] the contractor should contract or subcontract any of the aforesaid work falling within the normal trade jurisdiction of the union, said contractor shall contract or subcontract such work only to firms that are parties to an executed, current collective bargaining agreenent with Local Umion 100 .

421 U.S. at 620 . 
ted that the sole purpose of the picketing was to force Connell to sign the proposed agreement.72

Connell then sued Local 100 in state court seeking both injunctive and declaratory rehef under the Texas antitrust laws. The state court granted a temporary restraining order to halt the uiron's picketing, but Local 100 successfully removed the case to the Umited States District Court for the Northern District of Texas, and the state court injunction was vacated. Connell then signed the agreement under protest and amended its complaint to allege a federal as well as a state antitrust claim.

The district court denied Connell the declaratory and injunctive rehef it sought, holding that the construction industry proviso to section 8(e) of the National Labor Relations Act ${ }^{73}$ insulated the union's conduct from antitrust attack. ${ }^{74}$ The Court of Appeals for the Fifth Circuit affirmed, but on a narrower ground. The court ruled that, because plaintiff had shown no conspiracy between the union and an einployer group, the principal question was whether Local 100 was acting in pursuit of a legitimate labor objective. After noting that the union was apparently seeking to eliminate only coinpetition based on differences in wages and other labor standards, Judge Morgan held the union's conduct exeinpt. ${ }^{75}$

The Supreme Court granted certiorari and reversed. Justice Powell, writing for the 5-4 majority, held that the agreement between Local

\section{Id. at 631 .}

73. 29 U.S.C. \& 158(e) (1976). Section 8(e) provides that

[i]t shall be an unfair labor practice for any labor organization and any employer to enter into any contract or agreement, express or implied, whereby such employer ceases or refrains or agrees to cease or refrain from handling, using, selling, transporting or otherwise dealing in any of the products of any other employer, or to cease doing business with any other person, and any contract or agreement entered into heretofore or hereafter containing such an agreement shall be to such extent unenforcible [sic] and void ....

The construction imdustry proviso to this subsection, however, exempts from its operation any agreement "between a labor organization and an employer in the construction imdustry relating to the contracting or subcontracting of work to be done at the site of the construction, alteration, painting, or repair of a building, structure, or other work . . ." Id.

74. 78 L.R.R.M. 3012, 3014 (N.D. Tex. 1971).

75. 483 F.2d 1154, 1171 (5th Cir. 1973). Referring to the union's argument that the construction industry proviso to section 8(e) insulated the hot-cargo contract from antitrust attack, Judge Moran ruled that the legitimacy of union conduct for antitrust purposes was not controlled by whether it violated the ground rules of the NLRA. Id. at 1170. He accordingly found no reason for determining whether the proviso was applicable.

Judge Clark, who dissented from the Fifth Circuit's opinion in Connell, would have reached the section 8(e) proviso issue and would have ruled that the union's contract was unprotected. Id. at 1180-82 (Clark, J., dissenting). He also stated that the union conduct clearly restrained trade within the meaning of the Sherman Act, for it required Connell to boycott certain plumbing subcontractors. Id. at 1176, 1178 n.9. 
100 and Connell, which was neither within the context of a collective bargaining relationship nor restricted to a particular jobsite, was subject to antitrust scrutiny. After finding that the agreement in question created a direct market restraint with both actual and potential anticompetitive effects, the Court held that the exemption was unavailable because these effects did not "follow naturally" from the elimination of competition over wages and working conditions. ${ }^{76}$

Justice Stewart, joined by Justices Douglas, Brennan, and Marshall, dissented on the ground that the union's conduct was regulated solely by the National Labor Relations Act and was therefore immune from both federal and state antitrust prosecution.77 Relying on "considerable evidence in the legislative materials" related to the passage of the secondary activity and hot-cargo provisions of the Act, he concluded that Congress intended the labor laws to provide the exclusive remedies for the unlawful conduct alleged by Connell. ${ }^{78}$ Justice Douglas emphasized in a separate dissent that the key defect in Connell's coinplaint was the failure to allege or prove any conspiracy between the umion and the other unionized subcontractors. He reasoned that this infirmity in the complaint placed the union's conduct under the exclusive purview of the labor laws. ${ }^{79}$

A close analysis of Justice Powell's majority opinion in Connell reveals two subtle yet significant changes in the Court's approach to the labor exemption issue. First, the Court bifurcated the labor exemption into "statutory" and "nonstatutory" categories; second, it created a new "follow naturally" test, which places a great deal of emphasis on the market effects of union conduct. Each of these changes in labor exeinption analysis raises novel problems.

\section{A. Bifurcation of the Labor Exemption.}

The Court began its discussion of the labor-antitrust issue by dividing labor's exemption into statutory and nonstatutory categories.

76. 421 U.S. at 625.

77. Id. at 639 (Stewart, J., dissenting).

78. Id. at 650 (Stewart, J., dissenting). Both the majority opinion and the dissent in Connell apparently agreed that Congress rejected the use of antitrust sanctions to cnrb secondary union activities when it considered revising the NLRA in 1947. Compare id. at 634 \& n.15 (Powell, J.) with id. at 641 (Stewart, J., dissenting). Justice Powell found that this legislative choice had no relevance to the issue whether Congress intended to preclude antitrust attack on hot-cargo agrceinents, which were later forbidden as unfair labor practices under the Landrum-Griffin amendments to the NLRA enacted in 1959. Act of Sept. 14, 1959, Pub. L. No. 86-257, 73 Stat. 519 (current version at 29 U.S.C. § 158(e) (1976)). See 421 U.S. at 634. For an analysis of the weaknesses in Justice Powell's construction of the legislative history surrounding this issue, see St. Antoine, supra note 2, at 626-28; Comment, supra note 11, at 324-25.

79. 421 U.S. at 638 (Douglas, J., dissenting). 
The statutory exemption, according to the Court, is controlled by pertinent provisions of the Clayton ${ }^{80}$ and Norris-LaGuardia Acts, ${ }^{81}$ which protect activities undertaken by a union $\mathrm{m}$ its own self-interest and not in combination with a nonlabor group. ${ }^{82}$ The nonstatutory exemption, on the other hand, was developed by the courts to accommodate "the congressional policy favoring collective bargaining . . . and the congressional policy favoring free coinpetition in business markets ...."83 The nonstatutory exemption thus gives a ineasure of protection to agreeinents between unions and employers resulting froin the collective bargaining process. The Connell Court carefully limited the nonstatutory exemption, lowever, noting that the exemption did not offer protection "wlien a union and a nonlabor party agree to restrain competition in a busmess market." 84 Although this bifurcation is sound on its face, attempts to fit the facts of prior labor-antitrust cases within its framework yield sone troubling inconsistencies.

For example, Justice Powell referred to American Federation of Musicians v. Carroll ${ }^{55}$ as a statutory exeinption case. ${ }^{86}$ In Carroll the Court had ruled that certain pricing provisions imposed by a musicians union were exempt from the Sherman Act. ${ }^{87}$ The provisions were not contaimed in a collective bargaining agreement, nor were they imposed on anyone other than the complaining orchestra leaders, who were themselves inembers of the inusicians union. Accordingly, the unilateral nature of the union activities would have placed them under the rubric of the statutory exemption. These activities, however, which the Court imphed were tantamount to fixing the price of nusical entertainnient, ${ }^{88}$ surely could not be characterized as any of the activities specifically protected by the Clayton or Norris-LaGuardia Acts. ${ }^{89}$
80. 15 U.S.C. \& 17 (1976).
81. 29 U.S.C. $\$ \$ 101-115$ (1976).
82. See text accompanying notes 28-34 supra.
83. 421 U.S. at 622.
84. Id. at $622-23$ (citations omitted).
85. 391 U.S. 99 (1968).
86. 421 U.S. at $622-23$.

87. 391 U.S. at 102. The pricing provisions in question, which were contained in a "Price List Booklet" and were not a part of a collective bargaining agreement, required orchestra leaders to charge purchasers of music entertainment the sum of (1) the minimum wage for "sidemen" (i.e., instrumentalists); (2) a leader's fee, which was equal to twice the amount paid to a sideman; and (3) an additional eight percent to cover other expenses. Id. at 104.

88. Id. at 112-13.

89. Although the Carroll Court ultimately found that the union's activities represented a labor dispute within the meaning of the Norris-LaGuardia Act, it did not attempt to specify which if any of the specific provisions of that Act was applicable. Rather, the Court relied on the Jewel Tea "intimately related" test to find that the price-fixing provisions were actually a protection of the union's wages. Id. at 112 . Thus, it would appear that the Court in Carroll relied on a nonstat- 
Nevertheless, the Connell Court implied that the facts in Carroll epitomized a statutory exemption case, despite the absence of any strikes, boycotts, or related activity. ${ }^{90}$

Problems also spring from the Court's nonstatutory exemption. As mentioned previously, Justice Powell found that the purpose of the nonstatutory exemption was to accommodate the policies of the collective bargaiming process and the antitrust laws.91 This reasoning suggests that the nonstatutory exeinption was designed exclusively to consider union activity arising from the collective bargaining process, such as the union conduct reviewed in the Allen Bradley, Pennington, and Jewel Tea cases. If this suggestion is correct, however, a rather glaring void is created between the coverage of the statutory and nonstatutory exemptions in cases dealing with union conduct that is neither exclusively unilateral nor colmected with a collective bargaining relationship. ${ }^{92}$

The challenged conduct in Connell itself is difficult to place within this analytic framework. Local 100 admitted, and the Court acknowledged, that the union did not wish to represent Connell's employees or to bargain with Cormell on their behalf. ${ }^{93}$ Thus, Local 100's activities cannot be tied directly to the collective bargaining process. Moreover, the subcontractors with whon Local 100 had collective bargaining relationships were not involved with Local 100's organizational activities im any manner, and the record contained "no evidence that the union's

utory exemption case (Jewel Tea) to find that the union's conduct was exempt under the statutory criteriou.

90. One could also question whether the union conduct examined in Teamsters Union v. Oliver, 358 U.S. 283 (1959), would fall under the statutory or nonstatutory exeniption created by the Court in Connell. Oliver involved a collective bargaiming agreement between the Teamsters and a group of imterstate motor carriers, whicl provided for the imposition of a minimum rental fee on nonunion drivers who owned and drove their own trucks. Although a collective bargaining agreement was implicated, the Teamsters' unilateral conduct and the types of restraints considered by the Court were strikingly sunilar to those considered in Carroll.

91. See text accompanying note 83 supra.

92. The Hunt case could be viewed as involving only unilateral union conduct, and the Court's opinion could be read to support sucl a view. See 325 U.S. at 824 (the combimation in Hunt "was one of workers alone and what they refused to sell [to Hunt] was their labor"). The union in Hunt, however, was able to force the employer out of busmess only by resorting to the closed-shop agreements that it held with its other employers and by directing those employers to refram from dealing with Hunt. The union's directive could have violated the hot-cargo provisions of the National Labor Relations Act, had section 8(e) been in effect at the time the activities in Hunt occurred. Thus, although the Court chose to examine the union's conduct as separate froin an einployer combination, it was only through the closed-sliop agreenents and the nonlabor group's acquiesccnce to the union's demands that the boycott of Hunt was achieved. See text accompanying notes 41-44 supra. It is, therefore, unrealistic to characterize the union activity in Hunt as unilateral.

93. 421 U.S. at 619. 
goal was anything other than organizing as inany subcontractors as possible."94 These findings, coupled with Connell's obvious unwillingness to sign or to abide by the agreeinent in question, tend to underscore the unilateral nature of Local 100's conduct and suggest that the union's activities should be analyzed under the statutory exemption. Yet, despite these findings and without any discussion whatever, the Court examined Local 100's activities under the nonstatutory exemption.

Concern over the Court's handling of the statutory-nonstatutory dichotony involves much more than academic curiosity. If the nonstatutory exeinption were defined as broadly as the inajority in Connell suggested-to cover agreements imposed on employers by union activity outside the collective bargaming process- it would encompass almost every form of union conduct vulnerable to antitrust attack. Consequently, application of the statutory exemption would be hinited to very atypical circunistances. ${ }^{95}$ Tlins construction would require that most union conduct be scrutinized under the more rigorous nonstatutory standard, wlich, unlike its statutory counterpart, does not afford antitrust protection where a market restraimt is involved.

\section{B. The "Follow Naturally" Test.}

Applying the nonstatutory exemption to the union conduct in Connell, the Court ruled that although Local 100's objective was legal, the methods selected by the union to reach its goal were not. In this context the majority declared that Local 100 had forfeited its antitrust immunity by imposing restraints on the product market having "substantial anticompetitive effects, both actual and potential, that [did] not follow naturally from the elimination of competition over wages and working conditions." 96 The actual restraints found by the Court were the union's indiscriminate exclusion of nonunion subcontractors froin the market ${ }^{97}$ and the union's elimination of competition

94. Id. at 625 .

95. See Leslie, supra note 8. "As a practical matter, therefore, the statutory exemption is no longer a significant factor in labor antitrust cases." Id. 915. But see California Dump Truck Owners Ass'n v. Associated Gen. Contractors of America, 562 F.2d 607 (9th Cir. 1977). In Truck Owners the court considered the antitrust implications of certain provisions contamed in a collective bargaining agreement under both the statutory and nonstatutory exemptions. The court apparently assumed, without im-depth analysis, that the nonstatutory exemption was applicable to determine whether a union combination with umidentified coconspirators was protected, but that the statutory exemption was applicable to protect the collective bargaining agreement itself. Id. at 611.

96. 421 U.S. at 625 (einphasis added).

97. The Court found that Local 100 had excluded subcontractors from the market without regard to whether their coinpetitive advantages were derived from more efficient operating meth- 
among its organized subcontractors on subjects other than wages and working conditions through a most favored nations clause. ${ }^{98}$ The potential effect on competition was the possibility of the union's creating a geographical enclave for its subcontractors, similar to one found unlawful in Allen Bradley.99 Fmally, the majority ruled that because Local 100 had no interest in representing Connell's employees, the congressional policy promoting collective bargaining and peaceful resolution of labor disputes could offer no shelter to the union's conduct. ${ }^{100}$

The Court's analysis in Connell is curious in light of the laborantitrust precedent. The first restraint condemned by the Connell Court, the indiscriminate exclusion of nonunion subcontractors, was identical in effect to the market restriction allowed in Jewel Tea. The butchers unions in Jewel Tea prohibited their employers from selling meats after 6:00 p.m. Thus, as in Connell, the unions in Jewel Tea placed a direct restraint on the product market by eliminating all competition among the employer grocery stores during the evening hours. ${ }^{101}$ It is not possible to distinguish Jewel Tea and Connell on the ground that Local 100's restramt excluded subcontractors even though their competitive advantages may have been based on inore efficient operating methods rather than on substandard labor conditions. Jewel Tea and other grocery stores were able to prepackage neats with ex-

ods. Id. at 623 . The Court made this finding by assuming that there were in fact nonunion subcontractors in the Dallas area whose competitive edge had no relation to wages or other labor standards. There is no indication in any of the Court's opinions that this assumption was correct.

Had the union bcen able to prove that the nonunion subcontractors in Connell were able to underbid union contractors only on the basis of lower wages or differences in other labor standards, then a significantly different question would have been presented; namely, whether the Apex rule, see text accompanying notes 22-25 supra, would have provided an exemption for the union's conduct. Given the overall tenor of the Court's Connell opinion, however, it is doubtful that such a distinction would have inade any difference in the resnlt.

98. The Court did not refer to the precise terms of the clause, but its scope covered only wages and other labor concerns. Article XIX of the Master Collective Bargaining Agreement between Local 100 and the unionized contractors provided:

The Union further agrees that during the life of this Agreeinent that it will not grant

or enter into any arrangement or understanding with any other employer which provides for any wages less than stipnlated in this Agreement as the minimuni wages or for work under any more favorable terms or conditions to the employer than are expressed or unpled $\mathrm{m}$ this Agreement for less than the rate of wages indicated in this Agreentent.

Brief for Petitioner at 12 n.3, Connell Constr. Co. v. Plumbers Local 100, 421 U.S. 616 (1975) (einphasis omitted) (quoting Art. XIX of the Master Collective Bargaining Agreentent (A. 118)).

99. 421 U.S. at 625.

100. Id. at 626. The Court emphasized, however, that there was "no argument in [Connell], whatever its force in other contexts, that a restraint of this magnitude unight be entitled to an antitrust exemption if it were mcluded in a lawful collective-bargaining agreement." Id. at 625 26.

101. See discussion in text acconpanying notes 57-59 supra. 
pensive machinery and were therefore able to sell those meats through self-service operations without significantly infringing on the butchers' work jurisdiction or hours. ${ }^{102}$ Indeed, a fair reading of the Jewel Tea opinions strongly suggests that the unions' primary concern was protecting the working hours in the smaller shops that could not afford the prepackaging machinery, and that the unions iniposed across-theboard marketing hours restrictions only to keep peace among employers, if not to keep the smaller concerns in business. ${ }^{103}$ Thus, the unions in Jewel Tea, like the union in Connell, indiscrimmately excluded certain companies from the market even though their operations would not have interfered with the unions' hours and work jurisdiction.

The second anticompetitive effect found by the majority in Connell-the creation of a sheltered market-is also questionable. The Court premised its finding on the most favored nations clause of the union's collective bargaining agreement with its subcontractors. 104 Such a clause, however, is not anticoinpetitive per se. ${ }^{105}$ Indeed, the Jewel Tea collective bargaining agreements contamed such clauses. ${ }^{106}$ The Court in Pennington predicated antitrust liability on a most favored nations clause, but only because the clause was linked to an alleged employer conspiracy ainied at excluding smaller competitors from the coal market. 107 As Justice Douglas indicated in his separate dissent, the clause in Connell did not appear to assume this conspiratorial feature. ${ }^{108}$ The majority admitted as much by noting that the clause guaranteed the inembers of the Contractors Association, with whom Local 100 had collective bargaining contracts, only that the union would not undercut their competitive positions by offering more favorable terins on wages and working conditions to nonmembers. ${ }^{109}$

Despite the Jewel Tea and Pennington cases, however, the Connell majority asserted that the restriction on subcontracting illegally enhanced a sheltered market because it eliminated competition on all subjects covered by the multiemployer agreement between Local 100 and the Association, "even on subjects unrelated to wages, hours and

102. 381 U.S. at 738 (Douglas, J., dissenting).

103. See Cox, supra note 60 , at 324.

104. 421 U.S. at 623.

105. E.g., Associated Milk Dealers, Inc. v. Milk Drivers Union Local 753, 422 F.2d 546, 55254 (7th Cir. 1970). The NLRB has ruled that such clauses are nuandatory subjects of collective bargaining when no predatory purpose is involved. See, e.g., Dolly Madison Indus., Inc., 182 N.L.R.B. 1037 (1970).

106. See note 59 supra.

107. 381 U.S. at 665-66.

108. 421 U.S. at 638.

109. Id. at 623 n.1. 
working conditions." 110 This conclusion was valid in that competition would have been eliminated by the exclusion of nonunion firms. Nevertlieless, this exclusion was accomplished by the liot-cargo agreement, not by the most favored nations clause. The only possible relevance that the latter clause had to the elimination of competition was that it indirectly identified the beneficiaries of the market exclusion. In any case, the most favored nations clause was not probative on the issue of the means employed to effect sucli an exclusion.

The majority's analysis of the potential anticompetitive effects of the Connell agreeinent is also troublesome. The Court reasoned that because Local 100 had a well-defined geographical jurisdiction, it could have created a geographical enclave for itself and the members of the Association by refusing to sign collective bargaining contracts witli the latter's travelling competitors. ${ }^{111}$ The possibility of similar union abuses existed in Jewel Tea, however, since the unions in that case represented "virtually all butchers in the Chicago area."112 The majority highlighted the dangers of this enclave by comparing it to the "closed market in Allen Bradley," 13 but missing from such a comparison were the price fixing, bid rigging, and territorial allocation present in Allen Bradley, which contributed to the Court's refusal to allow the exemption. Also absent was any reference to the separate, yet pervasive, einployer conspiracy that the union in Allen Bradley aided and abetted. Finally, Justice Black's observation in Allen Bradley that the union's agreement "standing alone would not have violated the Sherinan Act"114 underscores the dissimilarities of the Court's approach in the two cases.

Another problem with the majority's approach in Connell was its unwillingness to test the legitimacy of the union's conduct in terms of traditional labor interests in organizing. The Court's perfunctory handling of this issue contrasts strongly with Justice White's opinion in Jewel Tea. For example, in Jewel Tea, Justice White placed great reliance on the union's vital interests by examining the butchers' resistance to overtinie work, the connection between working liours and the store operating hours, the feasibility of protecting the butcliers' concerns by less restrictive means, and the history of the collective bargaining negotiations between the union and the stores. ${ }^{115}$ Similarly, the majority in

110. Id. at 624 .

111. Id. at 625 .

112. 381 U.S. at 680.

113. 421 U.S. at 625.

114. 325 U.S. at 809.

115. 381 U.S. at 694-97. 
Connell might have considered, as the Fifth Circuit did below, factors such as the ambulatory nature of the construction industry, the particular difficulties encountered by Local 100 in its organizational drive, and the relationship, if any, between its need to unionize all subcontractors and its concerns over job preservation and wage security. ${ }^{116}$ The majority, however, declined to consider these factors without any explanation. Indeed, the only reference to labor policy in the Court's discussion of the labor exemption issue ${ }^{17}$ was its remark that simce Local 100 had no imterest in representing Connell's employees, federal policy favoring collective bargaining was not involved. ${ }^{118}$

The Court's "follow naturally" test strongly suggests, therefore, that a union's interests and the ineans available to protect those interests are irrelevant to the labor exemption question if it is shown that anticompetitive effects are present in the product market. In practical terins, the test requires an assessment of the merits of the antitrust allegations prior to and in place of an exainination of the labor exemption issue. ${ }^{11}$ This approach, in turn, apparently requires that the courts judge union conduct through a subjective determmation of whether the conduct is socially or economically objectionable, a rule that is both unsound and inprecise.

As our analysis of Connell demonstrates, the Court apparently has raised inore questions about labor's immunity from the antitrust laws than it has answered. The Connell rule has not been consistently interpreted by the lower courts and has led to conflicting results. Yet, despite the uncertainty engendered by the Connell liolding, its severe limitation on the scope of the statutory exemption as applied to atypical union conduct and its emphasis on the anticompetitive harms of such

116. Connell Constr. Co. v. Plumbers Union Local 100, 483 F.2d 1154, 1167-69 (5th Cir. 1973), rev'd, 421 U.S. 616 (1975).

117. The majority addressed the issue of whether Local 100's hot-cargo contract with Connell was within the section 8 (e) proviso, which allows the use of some hot-cargo agreements in the construction industry, see note 73 supra, but it is clear that this analysis was conducted apart from the discussion of the labor exemption issue. Thus, it is fair to say that the Court would have found the exemption imapphicable regardless of the 8(e) proviso issue. See Signatory Negotiating Comm. v. Local 9, Int'l Union of Operating Eng'rs, 447 F. Supp. 1384, 1391 (D. Colo. 1978). But see In re Bullard Contracting Corp., 464 F. Supp. 312 (W.D.N.Y. 1979).

118. 421 U.S. at 626.

119. The Court apparently attempted to dispel the notion that it was deciding both the antitrust and the labor exemption issues in Connell by remanding the case for reconsideration of whether Local 100's agreement had restrained trade "within the meaning of the Sherman Act." Id. at 637. Although the Court did not address whether the rule of reason or the stricter per se standard should be applied on reinand, its strong reliance on the market effects of the restraint and its disregard of the umion's purpose strongly implied that the per se rule was applicable. The district court was not required to pass on Local 100's liability imder the Sherman Act because the case was later settled out of court. 
union conduct are unmistakable. In effect, this approach renders antitrust and labor exemption questions inseparable.

\section{APPLICATION OF CONNELL}

The lower courts have apphed Connell in a variety of circumstances, ${ }^{120}$ and these cases demonstrate disagreement over the extent to which anticompetitive inarket effects control the exemption issue under the Court's "follow naturally" test, and the role, if any, that established labor law principles should have in determining that issue. Another question, which the Connell Court opted to bypass, has generated an equal aniount of controversy aniong the lower courts: whether the per se rule of illegahity under the Sherman Act is applicable to union conduct where the labor exenuption is found to be mapplicable.

\section{A. Market Effects and Labor Law Principles.}

The Third Circuit's treatment of the exemption issue in Larry $V$. Muko, Inc. v. Southwestern Pennsylvania Building \& Construction Trades Council ${ }^{121}$ is perhaps the best illustration of the problems associated with the Court's "follow naturally" test. Muko alleged that Long John Silver's, Inc., a national fast-food restaurant chain, violated the Sherman Act by agreeing with two union construction trade coun-

120. See, e.g., In re Bullard Contracting Corp., 464 F. Supp. 312 (W.D.N.Y. 1979) (antitrust allegation lodged against union to stay arbitration proceeding); Furriers Joint Council v. Ben Wirtzbaum Furs, Inc., 1979-1 Trade Cas. (CCH) If 62,443 (S.D.N.Y. 1978) (former employer raised antitrust allegation as defense to union's suit to coinpel arbitration); Frito-Lay, Inc. v. Retail Clerks Union Local 7, 452 F. Supp. 1381 (D. Colo. 1978) (antitrust suit against two unions that imposed ban on food supphers using route salesmen and delivery drivers to shelve and price products in their stores).

Perhaps the most significant issue now beginning to surface in the lower courts as a result of Connell is the extent to which the labor injunction may be on the rebound, an issue not addressed in this Article. The inajority in Connell touched on the issue in dicta by noting cryptically that there was no occasion for it to cousider whether the Norris-LaGuardia Act forbids an injunction "where the specific agreement sought by the union is illegal, or to determine whether, within the ineaning of the Norris-LaGuardia Act, there was a 'labor dispute' between [the] parties." 421 U.S. at 637 n.19. At least one litigant lias argued that Connell left open the possibility of issuing an injunction against union picketing, but the court declined to hold that Connell should be read so broadly. See Utilities Servs. Eng'r, Inc. v. Colorado Bldg. \& Constr. Trades Council, 549 F.2d 173, 178 (10th Cir. 1977). See also Marriott Corp. v. Great American Serv. Trades Council, 552 F.2d 176, 179-80 (7th Cir. 1977) (Lanham Tradeınark Act suit against a union). But $c f$. Suburban Beverages, Inc. v. Pabst Brewing Co., 462 F. Supp. 1301 (E.D. Wis. 1978) (denying a preliminary injunction without considering whether a "labor dispute" within the ineaning of the Norris-LaGuardia Act was involved). For an excellent comparative analysis of whether the term "labor dispute" should be narrowed for purposes of the antitrust laws, compare ATTORNEY GENERAL's National Committee to Study the Antitrust Laws, Report 298-300 (1955), with Cox, supra note 2 , at $267-70$.

121. 1978-2 Trade Cas. If 62,184, at 75,292 (3d Cir. 1978), rev'd en banc, 609 F.2d 1368 (3d Cir. 1979). 
cils to refuse to give Muko construction contracts in the Pittsburgh area solely because Muko was nonunion. This agreement, which the unions apparently obtained as a result of handbilling at a Silver's restaurant, ${ }^{122}$ was set out in a letter reflecting Silver's acquiescence to the unions' deniand that it use only union contractors in future construction of its restaurants. Prior to this agreement, Silver's had awarded construction contracts on the basis of the lowest bids regardless of union affiliation. It had awarded two such contracts to Muko. After signing this letter, Silver's invited Muko to enuploy union labor to qualify to bid on future contracts. Muko declined, and Silver's accordingly refused to allow Muko to bid on the available work. In response to Muko's antitrust claims, the defendant Trades Council argued that the labor exemption protected the conduct in question. A three-judge panel initially held that the exemption was applicable (Muko ), ${ }^{123}$ but the Third Circuit, sittmg en banc, reversed after a rehearing, holding that the unions' activities were nonexempt under the Connell rule (Muko In). ${ }^{124}$

Although recognizing that Connell was applicable in determining whether Silver's and the unions were exempt froin antitrust prosecution, Judge Aldisert, writimg for the majority of the three-judge panel in Muko I, found that the facts in Muko differed markedly from those im Connell. The judge first notcd that the unions in Muko required Silver's to use contractors certified by the unions. ${ }^{125}$ The court distimguished this certification requirenient from the restraint imposed in Connell, in which the union demanded that Connell use only those contractors with which it had collective bargaining agreenients. ${ }^{126}$ The court also noted plaintiff's failure to sliow that the multienuployer agreenient contained a most favored nations clause. ${ }^{127}$ In sum, the union activity under consideration in Muko, as opposed to that im Connell, was "low-key and narrow in scope; an activity 'intimately related to wages, lours and working conditions,' . . . ; an activity not accompanied by efforts to subject an entire imdustry to its demands, with the resultant substantial restraint in the product market."128 Based on these factual distmctions, the court in Muko $I$ lield that the unions' activities were exempt.

This decision and its rationale raise several very basic problems.

122. $1978-2$ Trade Cas. at 75,297 .

123. 1978-2 Trade Cas. I 62,184 (3d Cir. 1978).

124. 609 F.2d 1368 (3d Cir. 1979) (en banc).

125. 1978-2 Trade Cas. at 75,297 .

126. Id. See 421 U.S. at 624.

127. 1978-2 Trade Cas. at 75,297 .

128. Id. 
Notwithstanding the other differences between the union conduct in Connell and that in Muko, the fundamental reason for the Third Circuit's ruling was that the market effects in Muko were "low key" rather than "widespread" in character. 129 This ruling may have rested on undisputed facts, but the majority in Muko $I$ provided hittle guidance for determining the point at which union conduct crosses the forbidden line. Further, the majority's failure to discuss the possibility that the unions' conduct constituted a violation of section 8(e)-a factor given considerable weight by the dissenting judge ${ }^{130}$-is suspect. The majority examined section $8(\mathrm{~b})(4)$ of the National Labor Relations Act ${ }^{131} \mathrm{~m}$ a cursory fashion, but even that discussion is infirm smce the court ignored the landmark decision in the area of consumer handbilling, $N L R B v$. Servette, ${ }^{132}$ a holdmg that arguably supports the majority's conclusion. In failing to mention Servette, the majority overlooked the significance of labor principles in resolving the exemption question and rehed on the merits of the antitrust claim in the resolution of this issue. Thus, although the court tacitly acknowledged that the apparent legitimacy of the unions' conduct under prevailing labor precedent exempted it from antitrust scrutimy, the express language of the opinion predicated the labor exemption determination on antitrust grounds.

In any event, the "low key" test that the court apphed in the context of its market restramt analysis suffered a quick demise when the

129. Id.

130. Id. at 75,301-02 (Gibbons, J., dissenting). See note 73 supra.

131. 29 U.S.C. $\S 158(b)(4)(1976)$. The court cited the publicity proviso of this subsection, which reads as follows:

Provided further, That for purposes of this paragraph (4) only, nothing contained in such paragraph shall be construed to prohibit publicity, other than picketing, for the purpose of truthfully advising the public, including consumers and ineinbers of a labor organization, that a product or products are produced by an einployer with whom the labor organization has a primary dispute and are distributed by another employer, as long as such publicity does not have an effect of inducing any individual employed by any person other than the primary employer in the course of his einployinent to refuse to pick up, dehiver, or transport any goods, or not to perform any services at the establishment of the employer engaged in such distribution .....

1978-2 Trade Cas. at 75,298. The court concluded that "it would seriously undercut the protection offered by the publicity proviso to hold that, without more, concessions granted through legitimate handbilling under our labor laws could be subject to the antitrust laws." Id. at 75,297-98.

132. 377 U.S. 46 (1964). In Servette the Court considered whether a union violated section $8(b)(4)$ (i) and (ii) of the NLRA, 29 U.S.C. $\S 158($ b)(4)(i), (ii) (1976), by urging the inanagers of several retail food stores to refrain from handling the merchandise supplied by the urion's employer. The union had threatened to distribute landbills at those food stores, asking consumers to boycott Servette's products. The union hoped to gain the cooperation of the stores in this way. 377 U.S. at 49. The Court ruled that the conduct was not proscribed because the urion had asked the store officials only to exercise inanagerial discretion in refraining from handling Servette's products. Id. at 51 . Further, the umion's activity was deemed to be protected by section $8(\mathrm{~b})(4)$ 's handbilling proviso. Id. at 54-55. 
Third Circuit reversed Muko $I$ en banc. ${ }^{133}$ The court's opinion in Muko II reflected its narrow interpretation of the labor exemption under Connell. The court found that, like the union activity in Connell, the agreement between Silver's and the union councils prevented Muko froin competing for a portion of the available work in the Pittsburgh area. ${ }^{134}$ The court also noted that a jury could find that the agreement to use only certified contractors would significantly increase the total costs of building restaurants. ${ }^{135}$ Finally, the court concluded that the agreement itself had a potential for restraining competition because it excluded nonunion firms without regard to whether their competitive advantages had any relation to wages or working conditions. ${ }^{136}$ The court then held that these direct market restraints, imposed by an agreement between a union and a business orgnization outside a collective bargaining relationship, were not exempt under the Connell test: the anticompetitive effects did not follow naturally froin the elimmation of competition over wages and working conditions. ${ }^{137}$

The court's analysis in Muko $I I$, however, is again seriously flawed. There is a fundamental question whether any difference exists between the actual and the potential anticompetitive effects found by the court. Both restraimts were essentially the same form of conduct with the same effect: market foreclosure. In addition, the court siniply overlooked several important labor policy considerations in its opinion. The court did not inention that the unions' drive was aimed only at a nonindustry party rather than at all general contractors in the area. The Court in Connell had found this point important because, with all the general contractors involved, Local 100 could have created a geographical enclave to protect its local contractors. ${ }^{138}$ Further, although the Muko II court discussed the unions' conduct in the context of section $8(\mathrm{e}),{ }^{139}$ it failed to consider the unions' legitimate objective of preserving Silver's construction work. Fimally, the court made only cursory reference to Servette and made no mention of the possibility that Servette's interpretation of section 8(b)(4) might insulate the unions' handbilling activity froin reprisal under the labor laws. ${ }^{140}$

133. 609 F.2d 1368 (3d Cir. 1979) (en banc).

134. Id. at 1373-74 (quoting Connell Constr. Co. v. Plumbers Local 100, 421 U.S. at 625).

135. 609 F.2d at 1372 .

136. Id.

137. Id. at $1373-74$.

138. 421 U.S. at 625.

139. The court held that the unions' activities in fact violated section 8(e). $609 \mathrm{~F} .2 \mathrm{~d}$ at 1374 75.

140. Another point of contrast between the Third Circuit's two Muko opinions is the treatment each gave to the umions' picketing or handbilling activity. In Muko I the Court acknowledged that picketing occurred but failed to discuss the significance of this couduct in assessing the 
Admittedly, Muko II addressed only the narrow issue whether the directed verdict granted in $M u k o I$ was appropriate. Nonetheless, the Muko II decision shows the court's inability to set an appropriate standard for determining the applicability of the labor exemption. A comparison of the Muko opmions illustrates the difficulties of resolving the labor exemption issue on an ill-conceived and poorly defined marketeffects analysis, which gives little deference to appropriate labor law principles. If the Third Circuit's Muko II rationale were extended to its logical extreme, a court could find union conduct that is lawful under the labor laws to be the basis of an antitrust violation.

The district court's decision in Barabas v. Prudential Lines, Inc. ${ }^{141}$ came precariously close to reaching such a result. The issue in Barabas was whether a union and its individual meinbers were entitled to a preliminary injunction against the sale of thirteen ocean vessels by Prudential to Delta Steamship Lines, Inc. The union based its injunction claim on a clause in its collective bargaining agreeinent with Prudential. Prudential sought to prevent the injunction on the ground that enforcement of the clause violated section 8(e) of the National Labor Relations Act and section 1 of the Sherinan Act.

The clause in question required Prudential to insure by written agreement that any purchaser or transferee of its vessels would hire the complement of union einployees who were or would be assigned to duty on such vessels, and that the transferee would comply with all other terins and provisions of Prudential's collective bargaining agreement. ${ }^{142}$ During the sales negotiations, Delta refused to agree to such commitments because its workers were represented by a rival union. Accordingly, the sales contract for the vessels executed by Prudential and Delta contained a provision expressly disavowing the assuunption of "any obhgations resulting from any collective bargaining agreeinent

availability of the labor exemption. Conversely, the panel in Muko II discussed the validity of both the picketing and handbilling under the NLRA in an attempt to resolve this issue. Compare Larry V. Muko, Inc. v. Southwestern Pa. Bldg. \& Constr. Trades Council (Muko I), 1978-2 Trade Cas. at 75,297, with Larry V. Muko, Inc. v. Southwestern Pa. Bldg. \& Constr. Trades Council (Muko II), 609 F.2d at 1375. The question is important, for the proviso to section 8(b)(4) protects "publicity, other than picketing, for the purpose of truthfully advising the public . . ." 29 U.S.C. § 158(b)(4) (1976) (emphasis added). See, e.g., Local 54, Sheet Metal Workers Int'l Ass'n, 179 N.L.R.B. 362 (1969). Of course, the majority in Muko II rendered this issue academic by finding that the arguable legitimacy of the conduct begetting the agreement was irrelevant to the exemption issue if the agreement itself was illegal under section 8(e). The court, however, implied that handbilling intended to compel a section $8(e)$ agreement is not protected by the publicity proviso to section $8(b)(4)$.

141. 451 F. Supp. 765 (S.D.N.Y.), affd per curiam, 557 F.2d 184 (2d Cir. 1978).

142. $I d$. at 768 . 
or other understanding . . , ,143 including the restraint-on-transfer clause.

The union sought to enforce the restraint-on-transfer clause through arbitration. Subsequently, an arbitrator issued a decision requiring Prudential to abide by the terms of the clause. ${ }^{144}$ In a related unfair labor practice proceeding between Prudential and the union, the Regional Director of the National Labor Relations Board approved a settleinent agreeinent between the parties. ${ }^{145}$ The agreeinent provided that, although the restraint-on-transfer clause was on its face violative of section 8(e) of the National Labor Relations Act, enforcement of the arbitrator's award "would not constitute unlawful conduct within the meaning of Section 8(e) of the Act." 146

Examining the union's request for a preliminary injunction under standard criteria, ${ }^{147}$ the court ruled that the union had shown a probability of success on the merits as against Prudential's defense that the clause violated section 8(e). It based this ruling on the National Labor Relations Board Regional Director's approval of the settlement agreement, which allowed enforcement of the restraint-on-transfer clause. The court added, however, that even though the clause niay have been lawful under the labor laws, Prudential had shown a substantial probability of prevailing on its second claim that the nonstatutory labor exemption was inapplicable and that the union had violated the antitrust laws by seeking to enforce the restraint-on-transfer clause. The court reasoned that the nonstatutory exemption may have been unavailable to the union because the clause directly restricted Prudential's ability to sell or transfer its vessels, ${ }^{148}$ and that enforceinent of the

143. Id.

144. Id.

145. Id. at 768-69.

146. Id. at 769. There was no explanation or discussion of this unusual approval in the court's opinion. Contra, NLRB v. National Maritime Union, 486 F.2d 907 (2d Cir. 1973), ccrt. denied, 416 U.S. 970 (1974).

One possible explanation for the Regional Director's approval is that the arbitrator read the clause in question only to protect the jobs of the employees who were currently employed by the vessel owner, rather than to protect union jobs in general. Such a reading would have saved the clause, which on its face constituted an unlawful secondary activity. Cf. National Woodwork Mfrs. Ass'n v. NLRB, 386 U.S. 612, 635 (1967) (holding that section 8(e) does not prohibit agreeinents made and maintained for the purpose of pressuring einployers to preserve work traditionally done by union einployees).

147. The court recognized that the anti-injunction provisions of the Norris-LaGuardia Act, 29 U.S.C. $§ 107$ (1976), were implicated but asserted that it was "unnecessary" to determine whether they were applicable because the injunctive relief was denied in any event. $451 \mathrm{~F}$. Supp. at 769 n.2.

148. Id. at 771. The court curiously premised this finding on the dissenting opinion of Judge Lumbard in Commerce Tankers Corp. v. National Maritime Union, 553 F.2d 793 (2d Cir.), cert. 
clause was probably an antitrust violation because it would reduce the efficiency of the domestic maritime industry and would result in the loss of employment opportunities for other American union seamen. ${ }^{149}$ Thus, the court intimated that the union conduct could violate the antitrust laws, notwithstanding its apparent lawfulness under the labor laws.

The Second Circuit's decision in Commerce Tankers Corp. v. National Maritime Union ${ }^{150}$ involved similar facts, and that court's handling of the exemption and antitrust problems is equally disquieting. In Commerce, plaintiff's claim was virtually identical to the claim in Barabas: Commerce argued that because the National Maritime Union's restraint-on-transfer clause violated the labor laws, the umion's activities in attemptimg to enforce the clause were unprotected by the nonstatutory exemption. Consequently, enforcement of the clause would constitute an antitrust violation. ${ }^{151}$ One significant difference between Commerce's claim and plaintiff's claim in Barabas was that, in the former case, the National Labor Relations Board had already held that the National Maritime Union's clause was a violation of section 8(e), and this ruling had been affirmed by the Second Circuit. ${ }^{152}$

The majority in Commerce avoided answering Commerce's exemption arguments directly, holding that this issue should first be determined in the district court after further findings and briefs from both parties. ${ }^{153}$ The court noted in dicta, however, that its prior holding on the section 8(e) issue did not necessarily determine the labor exemption issue; it merely lent support to Commerce's claim that the nonstatutory exeinption was unavailable. ${ }^{154}$

denied, 434 U.S. 923 (1977), which involved a similar restraint-on-tranfer clause in another collective bargaining agreement. See discussion in text accompanying notes 150-58 infra.

149. $451 \mathrm{~F}$. Supp. at 771 . The court's analysis on this point is equally curious. In considering whether the clause unreasonably restrained trade, the court claimed that it had to balance "the public interest in a competitive domestic maritime industry against the public interest sought to be protected by the labor laws." Id. (emphasis added). One could certainly question why the court did not balance those interests in determining the exemption question, as Jewel Tea directs, rather than in determining the substantive antitrust violation. Moreover, the court did not weigh the possible job preservation interests of the union, as it considered only the supposed "loss of employment opportunities for American union seamen" in general. Id. In ignoring the union's vork preservation motive, the court in Barabas has implicitly abandoned the Jewel Tea "intimately related" test. Because the court totally disregarded the umon's interest in work preservation, it was clearly unnecessary to cousider whether the challenged union activity was "intimately related" to this legitimate union objective.

150. 553 F.2d 793 (2d Cir.), cert. denied, 434 U.S. 923 (1977).

151. 553 F.2d at 798 .

152. NLRB v. National Maritime Umion, 486 F.2d 907 (2d Cir. 1973), cert. denied, 416 U.S. 970 (1974).

153. $553 \mathrm{~F} .2 \mathrm{~d}$ at 802 .

154. Id. The majority relied on Connell and intimated that because the restraint-on-transfer 
Judge Lumbard dissented in part in Commerce, arguing that the case should be remanded to the district court for the limited purposes of assessing dainages and entering judginent. $155 \mathrm{He}$ asserted that the court's prior finding of illegahty under section 8(e), coupled with the prevention of Commerce's selling its ship, was sufficient to strip the National Maritime Union of its nonstatutory exemption under the Connell "follow naturally" standard. ${ }^{156} \mathrm{He}$ also stated that there was suffcient evidence to support the finding of an antitrust violation against the National Maritime Union under either the per se or the rule of reason approach. ${ }^{157}$ Thus, Judge Lumbard read Connell to require autoinatic denial of the labor exemption once a violation of the labor laws was found. This approach would foreclose all analysis of the actual or potential market effects of the union's conduct. In Judge Lumbard's view, the prior ruling on the section 8(e) violation created an inference that the restraint-on-transfer clause might eliminate competition in ways that did not follow naturally from the umion's concern over wages and working conditions. ${ }^{158}$

The Third Circuit adopted Judge Luubard's view of the labor exeinption question in Consolidated Express, Inc. v. New York Shipping Association. ${ }^{159}$ The Consolidated decision involved the lawfulness of the union's atteinpts to enforce certain provisions contained in a collective bargaining agreement and a supplemental accord executed by the New York Shipping'Association and the International Longshoreınen's Association. In ruling that the union's conduct violated the antitrust laws, the Third Circuit pushed the Connell "follow naturally" test to its logical extrene and fashioned perhaps the most novel apphication of the labor exeinption to date.

The contract provisions at issue in Consolidated stemmed from a labor dispute dating back to 1958 between the New York Shipping Association and the International Longshorenen's Association. 160 This dispute concerned the practice of "containerization," the packing and

clause was contained in a collective bargaining agreement, it might be sheltered from antitrust attack. Id. at 801. This issue, however, was left open in Connell. Justice Powell stated ony that no argument could be inade that Local 100's hot-cargo agrceinent was protected, because there was no collective bargaining agreement at issue in Connell. 421 U.S. at 625-26.

155. 553 F.2d at 803 (Lumbard, J., dissenting in part).

156. Id. at 803-04 (Luinbard, J., dissenting in part).

157. $I d$. at 804 .

158. Id.

159. 602 F.2d 494 (3d Cir. 1979).

160. For an extended discussion of the controversy, see 602 F.2d at 498-501. See also Intercontinental Container Transp. Corp. v. New York Shipping Ass'n, 426 F.2d 884, 888 (2d Cir. 1970); Consolidated Express, Inc. v. New York Shipping Ass'n, 452 F. Supp. 1024, 1026-31, 1042 (D.N.J. 1978), aff'd in part and rev'd in part, 602 F.2d 494 (3d Cir. 1979). 
unpacking of ocean cargo in large containers away from the docks. Consolidated and other containerization firms had gradually reduced the amount of work available for longshoremen, who historically had performed the packing and unpacking at the docks. ${ }^{161}$ The New York Shipping Association and the International Longshoremen's Association had attempted to preserve the longshoremen's work by executing the Rules on Contamers and the Dublin Supplement, ${ }^{162}$ which imposed heavy fines on vessel owners who supplied containers to firms like Consolidated.

Prior to filing its antitrust action agamst the unions, Consolidated had lodged an unfair labor practice charge agamst the International Longshoremen's Association, asserting that the agreements in question and the union's enforcement efforts constituted violations of section $8(\mathrm{e})^{163}$ and section $8(\mathrm{~b})(4)(\mathrm{i})(\mathrm{B})^{164}$ of the National Labor Relations Act. The National Labor Relations Board upheld Consolidated's charges, concluding that the International Longshorenien's Association's activities were unrelated to job preservation and consequently had an unlawful secondary objective. ${ }^{165}$ The Board's ruling was subsequently affirmed by the Second Circuit. ${ }^{166}$

The labor exemption issue before the Third Circuit in Consolidated, therefore, was whether a National Labor Relations Board finding of illegality was im and of itself sufficient to oust the union's conduct froin the protcction of the nonstatutory exemption. After an exhaustive

161. 602 F.2d at 498.

162. The terms of both agreements are noted in the district court's opinion, $452 \mathrm{~F}$. Supp. at $1027-28$ n.3.

163. 29 U.S.C. $§ 158(\mathrm{e})$ (1976). See note 73 supra.

164. 29 U.S.C. $\$ 158$ (b)(4)(ii)(B) (1976).

165. International Longshoremen's Ass'n, 221 N.L.R.B. 956 (1975).

166. International Longshoremen's Ass'n v. NLRB, 537 F.2d 706 (2d Cir. 1976), cert. denied, 429 U.S. 1041 (1977). The Second Circuit distimguished its prior decision, International Container Transp. Corp. v. New York Shipping Ass'n, 426 F.2d 884 (2d Cir. 1970), in which it held that the union's conduct was directed toward job preservation, by stating that it arose in the context of an antitrust violation. 537 F.2d at 708 n.1. In International Longshoremen's Ass'n v. NLRB, 560 F.2d 439 (Ist Cir. 1977), the First Circuit held a strikingly similar agreement, which involved the Rules on Containers, to be a violation of section 8(b)(4)(ii)(B). The Fourth Circuit reached essentially the same conclusion in vacating a district court's denial of a temporary injunction agamst the Rules requested by the NLRB's Regional Director. Humphrey v. International Longshoremen's Ass'n, 548 F.2d 494 (4th Cir. 1977).

Despite these nearly uniform rulings, the District of Columbia Circuit, in International Longshoremen's Ass'n v. NLRB, 613 F.2d 890 (D.C. Cir. 1979), cert. granted, 100 S. Ct. 727 (1980), held that the ILA's Rules on Containers were related to job preservation rather than work acquisition, and that they were therefore lawful under the NLRA. The court reasoned that the NLRB erred by failing to examine "all the surrounding circumstances" to determine whether the ILA's activities were related to job preservation. $613 \mathrm{~F} .2 \mathrm{~d}$ at 909 . The court held that this sort of extensive analysis was required by the holding in National Woodwork Mfrs. Ass'n v. NLRB, 386 U.S. 612 (1967). 613 F.2d at 910 . 
review of labor exemption precedent, the court drew a distinction between an action under section 16 of the Clayton Act seeking injunctive relief and an action under section 4 seeking treble damages. ${ }^{167}$ The court concluded that conduct found to be an unfair labor practice could derive no protection from the nonstatutory exemption in suits for injunctive relief. ${ }^{168}$ Indeed, the Third Circuit's ruling implied that a finding of illegality under section 8(e) not only reinoved the exemption but also proved that the challenged conduct violated the antitrust laws. ${ }^{169}$ On the other hand, the same conduct might still be immune froin antitrust prosecution in treble-dainage suits.

The court's distimction between injunctive and treble-damage antitrust actions was based on two premises: a reluctance to disturb the collective bargaining process and the peaceful, voluntary adjustment of labor disputes, and a concern that the defendants in Consolidated might have "reasonably believed that their agreennent was directly related to the lawful goal of work preservation." 170 There were several reasons for this second concern. Prior to the National Labor Relations Board's disposition of the matter, the Second Circuit had ruled in Intercontinental Container Transport Corp. v. New York Shipping Association ${ }^{171}$ that the Rules on Contamers were immune froin antitrust attack, because their objective was "the preservation of work traditionally performed by longshoremen covered by the agreeinent" 172 and that the union had acted solely in its own self-interest in demanding that the Rules be enforced. ${ }^{173}$ Moreover, it appears froin the district court's decision in Consolidated that a presidentially appointed inediator not only encouraged but also participated in the negotiations between the New York Shipping Association and the International Longshoremen's Association leading up to the adoption of the Rules. ${ }^{174}$ As the district court aptly noted in Consolidated: "the Rules were put into effect during a period when all official indications suggested that they were legiti-

167. 602 F.2d at 520-21.

168. Id. at 521 .

169. Id. at 519. The court held that enforcement of the Rules on Contamers and the Dublin Supplement was not exempt under the Sherman Act and that it could be enjomed under the Jewel Tea and Connell tests. Id. at 516-19. Without any further analysis of the substantive antitrust allegations, the court concluded: "If this were an action for imjunctive relief brought pursuant to $\$ 16$ of the Clayton Act, an imjunction . . . plainly would be required." Id. at 519. The court's reliance on the Jewel Tea and Connell rulings in this context is odd; both cases dealt only with the exemption question and not with the antitrust issues.

170. Id. at 520 .

171. 426 F.2d 884 (2d Cir. 1970).

172. Id. at 887 .

173. Id. at 888 .

174. Consolidated Express, Inc. v. New York Shipping Ass'n, 452 F. Supp. 1024, 1042 (D.N.J. 1978), aff'd in part and rev'd in part, 602 F.2d 494 (3d Cir. 1979). 
mate."175

In apparent reliance upon these unusual circumstances, the Third Circuit devised a new labor exemption, which it referred to as the section 4 exemption defense. ${ }^{176}$ In order to make a prima facie showing agaimst antitrust immunity in section 4 cases, a plamtiff must show only that the challenged activity is illegal under federal labor law. Even if this eleinent is proved, however, the parties to the collective bargaining agreennent may still avail theinselves of the exemption if they can show that the restraint on the secondary nnarket was "intimately related" to an object of collective bargaining thought to be legitimate at the time of the agreement and that the restraint went no further than was necessary to accomphish that object. ${ }^{177}$ As a caveat, the court adinonished that the section 4 exemption defense would be unavailable if predatory intent were involved in the restraint. ${ }^{178}$

The Third Circuit's opimion in Consolidated is bewildering in a number of respects. First, the court did not explain its holding that a violation of section 8(e) may automatically constitute an antitrust violation in actions for injunctive relief. As Judge Weis suggested in his dissent, every court that has considered the labor exemption issue has recognized the need to separate the exemption inquiry froin the antitrust liability inquiry. ${ }^{179}$ Second, the inajority in Consolidated did not consider the impact that the Norris-LaGuardia Act would have upon a district court's authority to enter an injunction in cases involving labor disputes. The court nnay have taken the view that the union's conduct in Consolidated was unlawful and that it could not be characterized as a labor dispute within the ineaning of the Norris-LaGuardia Act, but it is not at all clear that the court even entertamed such an interpretation of the Act's terms. ${ }^{180}$ Finally, the Consolidated decision makes labor's exenuption turn on the opimon of those involved in collective bargaining negotiations on the lawfulness of the agreement under the labor laws. The thought that a judge or jury might later pry into the subtle nuances of the collective bargaining process long after a conclusion of negotiations may teniper union demands to soine extent, but such an

175. Id.

176. 602 F.2d at 521 .

177. $I d$.

178. $I d$.

179. Id. at 528 (Weis, J., dissenting). In practice, however, these two inquiries have frequently been counbined, and this problein has been perpetuated by the Connell "follow naturally" test. See text accompanying note 119 supra.

180. The court probably ignored the issue because of the cease and desist order that had been issued by the NLRB and enforced by the Second Circuit. The parties certainly had no reason to brief the issue since the only remedy Consohdated sought was treble damages. 
intrusion may well do more to unsettle the fragile balance sought to be achieved in that process.

The court's holding in Consolidated again points up the ambiguity of the Connell "follow naturally" test. In fact, this ambiguity has arisen in a variety of court opinions holding that conduct arguably lawful under the labor laws may nevertheless be subject to antitrust attack; that a violation of the labor laws does not necessarily determine whether the labor exemption is available; and that a violation of section 8(e) not only renders the labor exemption inapphicable but also establishes an antitrust violation in actions seeking only injunctive relief.

\section{B. Rule of Reason or Per Se Approach.}

Once the court has found that the union-employer conduct is nonexempt from antitrust prosecution, it must then ascertain whether to apply the rule of reason or the per se rule of illegahty under the Sherman Act. Although the Supreme Court has never addressed this issue directly, ${ }^{181}$ the need for some precise direction in this area is pressing. Apphication of the per se rule pretermits consideration of the resulting market effects, the characteristics of the industry involved, and the purpose of or motivations behind the restramts imposed, while all of these factors are relevant under the more extensive rule of reason approacl. ${ }^{182}$ Accordingly, if plaintiffs prove the elements of typical per se

181. The Court has hinted in dicta that the per se rule may be applicable to union-employer conduct. In Apex Hosiery, for example, the Court stated that the Sherman Act "makes no distinctions between labor and nonlabor cases," 310 U.S. at 512 , and that it should be applied impartially to the activities of industry and labor alike. Id. The various opinions in both Jewel Tea and Pennington also indicate the Court's belief that settled antitrust primciples are appropriate and apphicable in resolving substantive antitrust claims agamst union-employer combinations. See Local 189, Amalgamated Meat Cutters v. Jewel Tea Co., 381 U.S. at 693 n.6 (plurahity opimion); $i d$. at 736-37 (Douglas, J., dissenting); UMW v. Pennington, 381 U.S. at 673 (Douglas, J., concurring).

These opinions, however, are far froin conclusive on whether the per se rule is applicable. In Apex Justice Stone specifically declined to rule on the issue, 310 U.S. at $507 \mathrm{n} .25$, and the Court later interpreted Apex as drawing a distinction between "coinbmations having commercial objectivcs" and "labor unions, which normally have other objectives," Klor's, Inc. v. Broadway-Hale Stores, Inc., 359 U.S. 207, 213 n.7 (1959); accord, Note, supra note 8, at 831.

Justice Douglas apparently viewed the restramt in Jewel Tea as a form of a group boycott, see 381 U.S. at 737 (citing Fashion Originators' Guild of America, Inc. v. FTC, 312 U.S. 457 (1941)), but Justice White considered the restraint a limitation on busmess hours and apparently would have applied a rule of reason analysis. See 381 U.S. at 693 n.6 (citing Chicago Bd. of Trade v. United States, 246 U.S. 231 (1918)). Moreover, the courts that considered the restraint in Pennington on remand did not apply the per se rule. See, e.g., South-East Coal Co. v. Consolidation Coal Co., 434 F.2d 767 (6th Cir. 1970), cert denied, 402 U.S. 983 (1971). See also Ramsey v. UMW, 401 U.S. 302 (1971).

182. Compare Chicago Bd. of Trade v. United States, 246 U.S. 231 (1918) (the oft-quoted rule of reason case), with Northern Pac. Ry. v. United States, 356 U.S. 1, 5 (1958) ("[T] here are certain agreements or practices which because of their pernicious effect on competition and lack of any 
restraints such as price fixing or group boycotts, then the courts will presuine adverse market effects and the absence of any justification for the restraint. ${ }^{183}$

The lack of guidance from the Supreme Court on this issue has generated as much debate and confusion among the lower courts as has the proper application of the Court's "follow naturally" test. The Second Circuit, for exainple, avoided deciding this issue in Commerce, noting only that there was a substantial question whether a per se approach should be utilized to judge nonexeinpt labor conduct. ${ }^{184}$ Similarly, in Muko II the court refused to commit itself regarding the application of the per se rule and rule of reason approaches, although its reservation stemmed from its inability to characterize the unions' conduct as either a group boycott or soine lesser restraint. ${ }^{185}$ In dictuin, however, the court suggested that evidence of a classic group boycott adduced on remand would warrant application of the per se rule. ${ }^{186}$

Only the Third, Eighth, and Ninth Circuits have confronted this question directly. Regrettably, the results these courts have reached are far from harmonious. In Ackerman-Chillingworth, Inc. v. Pacific Electrical Contractors Association, ${ }^{187}$ the Ninth Circuit considered the appropriateness of applying the per se rule to a collective bargaining agreenent requiring all employers to use only one insurance firm for their workmen's coinpensation coverage. The court ruled that the record did not support a finding that the union and its einployer group had committed a per se violation of the Sherman Act. The court based its decision on two key factors: the lack of harm to the plaintiffs as a result of the plan, and the absence of coercion on the part of the trade association's representative who was responsible for soliciting the insurance contracts froin the signatory contractors. ${ }^{188}$ The court apparently rehed on these factors alone, failing to consider either the union's interests in the plan or the policy underlying peaceful collective bargaining. The court observed only that the urion-einployer group did

redeeming virtue are conclusively presumed to be unreasonable and therefore illegal without elaborate inquiry as to the precise harm they have caused or the business excuse for their use"). See generally Von Kalinowski, The Per Se Doctrine-An Emerging Philosophy of Antitrust Law, 11 U.C.L.A. L. REV. 569 (1964).

183. See, e.g., United States v. Sealy, Inc., 388 U.S. 350 (1967) (division of markets); Radiant Burners, Inc. v. Peoples Gas Light \& Coke Co., 364 U.S. 656 (1961) (boycotts); Northern Pac. Ry. v. United States, 356 U.S. 1 (1958) (tying arrangements); Umited States v. Socony-Vacuum Oil Co., 310 U.S. 150 (1940) (price fixing).

184. $553 \mathrm{~F} .2 \mathrm{~d}$ at 802 .

185. $609 \mathrm{~F} .2 \mathrm{~d}$ at $1375-76$.

186. Id. at 1376 .

187. 579 F.2d 484 (9th Cir. 1978), cert. denied, 439 U.S. 1089 (1979).

188. 579 F.2d at 490 . 
not share any of the characteristics of the groups generally condemned as unlawful per se. ${ }^{189}$

The unique characteristics of the group charged with violating the antitrust laws also led the Eighth Circuit to refuse to apply the per se rule in Mackey v. National Football League. ${ }^{190}$ At issue in Mackey was the "Rozelle Rule," which allowed the Commissioner of the National Football League to coinpensate a club for the loss of a player who had become a free agent and had signed a contract with another league team. ${ }^{191}$ The National Football League Players' Association alleged that the Rozelle Rule denied them the right to contract freely for their services, and that its enforcement constituted a concerted refusal to deal, illegal per se under the Sherman Act. ${ }^{192}$ Relymg on the unique nature of the league- -which the court observed had some of the characteristics of a jomt venture ${ }^{193}$ - on the lack of complete elimination of competition for the players' services, and on the district court's exhaustive inquiry into the operation of the league, the Eighth Circuit concluded that the Rozelle Rule did not warrant per se treatment. ${ }^{194}$ As in Ackerman-Chillingworth, the court did not weigh the union's interest or lack of interest in the restraint resulting from the Rozelle Rule or the

189. Id. at 490 n.7.

190. 543 F.2d 606 (8th Cir. 1976), cert. dismissed, 434 U.S. 801 (1977). For a discussion of Mackey and of whether the per se rule should be applied to the arguably unique professional sports industry, see J. WeISTART \& C. Lowell, The LAW of SpORTS \& 5.07, at 608-13, 617-21 (1979).

191. 543 F.2d at $610-11$.

192. Id. at 609. Before addressing the substantive antitrust claim, the Eighth Circuit considered whether the labor exemption was applicable to shield the Rozelle Rule from antitrust attack. The court devised an elaborate test, which it deduced from labor-antitrust cases:

First, the labor pohicy favoring collective bargaining may potentially be given pre-eminence over the anti-trust laws where the restraint on trade primarily affects only the parties to the collective bargaining relationship. Second, federal labor policy is implicated sufficiently to prevail only where the agreement sought to be exempted contains a mandatory subject of collective bargaining. Finally, the pohicy favoring collective bargaining is furthered to the degree necessary to override the antitrust laws only where the agreement sought to be exempted is the product of bona fide arm's-length bargaining.

Id. at 614 (citations omitted). Although the court found that the Rozelle Rule was a mandatory subject of collective bargaining, $i d$. at 615 , it held the exemption inapplicable because there had been no bona fide arn's-length bargaining between the NFL Players Association and the league. Id. at 616. This ruling was based on the district court's finding that there was no quid pro quo for including the Rule in the collective bargaining agreement in terins of increased pension benefits or other labor gains. Id.

The Mackey court's "arin's length" criterion sets a dangerous precedent. It allows courts to reopen the collective bargaining process for the purpose of weighing the many varied and intricate bargaining positions taken by the respective parties, and it effectively requires courts to determine whether the provisions agreed upon are fair or beneficial to the parties. The courts are particularly unsuited to assume such a role. See Cox, supra note 60, at 326.

193. $543 \mathrm{~F} .2 \mathrm{~d}$ at 619 .

194. Id. at $619-20$. 
collective bargaining process itself in arriving at this conclusion. Nor did the court deein it relevant that the restraint was in the labor rather than the product market. ${ }^{195}$

While the Third Circuit also deemed these considerations irrelevant in the Consolidated case, it held that the per se rule was applicable, basmg its decision on three grounds. First, unlike the courts im Ackerman-Chillingworth and Mackey, the Third Circuit had no difficulty in finding that the union-employer combination had "horizontal, vertical and coercive aspects," all of which were present in the business combinations previously subjected to the per se rule. ${ }^{196}$ The conspiracy had horizontal anticompetitive effects in precluding Consolidated and the other boycott victims from rendering services identical to those provided by some of the members of the combimation. ${ }^{197}$ The vertical element was apparently supplied by the vessel owners' participation in the combination, because they supplied the containers that the boycott victims needed to operate. ${ }^{198}$ The combination was also coercive in that the boycott victims were required to change their methods of operation to allow the International Longshoremen's Association labor to do the packing and unpacking. ${ }^{199}$ Second, the majority in Consolidated found that the Supreme Court opinions in both Jewel Tea and Pennington supported, rather than prevented, the application of the per se rule to conduct arismg from collective bargaining agreements. Relymg on the dissenting opinions of Justices Goldberg and Douglas, the majority opined that settled antitrust principles such as the per se rule were appropriate and applicable to nonexempt union-employer activities. ${ }^{200}$ Finally, the court rejected the notion that labor's legitimate interests in the collective bargaining process were adequate justification for applying the rule of reason. Noting that these imterests nerited attention in determining whether the section 4 exemption defense was available to the union-employer's conduct in the first place, the court reasoned that it would be redundant to weigh those imterests agam in deciding the antitrust liability question. ${ }^{201}$

In sum, the lower courts either have dodged the issue of whether

195. As noted above, however, the Eighth Circuit apparently took both these considerations into account in determining whether to apply the labor exemption. See note 192 supra.

196. 602 F.2d at 522. It is imteresting to note that the court found a second union, the Teamsters, to be the excluded horizontal competitor of the International Longshoremen's Association. Id.

197. Id.

198. See id.

199. Id.

200. Id. at 523. For a discussion of the problems in relying on those cases to support application of the per se rule, see note 181 supra.

201. 602 F.2d at 523-24. 
the per se rule should be apphed or have apphed it in conflicting ways. Most of the probleins associated with applying the per se rule to collective bargaining conduct he in characterizing the union-einployer combination as one of the horizontal or vertical combinations that the courts consider in the context of classic commercial restraints. Equally troublesome-with the exception of Consolidated -are the courts' failures to consider the collective bargaining process or to distinguish between labor and busmess-oriented restraints in determining the appropriateness of the rule of reason approach.

\section{A More Practical Aprroach}

The Connell "follow naturally" test and the reasons given by the lower courts for applying either the rule of reason or the per se rule to union-employer conduct are wholly unacceptable primciples upon which to decide the sensitive issues of antitrust-labor pohcies. As shown in the preceding section, the Connell "follow naturally" test in general is devoid of any bright-line rules for determining the circumstances in which the labor exemption should be apphed. In particular, the test does not establish the types of adverse inarket effects, if any, that should or should not be permitted when juxtaposed with labor policies. Nor does the test give any guidance on the role that traditional labor law primciples should play in protecting anticoinpetitive unionemployer conduct. The rule of reason-per se rule controversy is equally devoid of precedential guidance. The courts' choice between these two rules is controlled exclusively by the courts' ability to match the configuration or conduct of a union-einployer conibination with one of the various models created by the courts in considering purely commercial conduct. This matching process either ignores collective bargaming policies or relegates then to a subordinate position.

There is an approach to the problein that will avoid many, if not all, of the pitfalls created by the "follow naturally" test and by the courts' handling of the rule of reason-per se rule controversy. This approach inay require a significant change in the manner and order in which the labor-antitrust policies are considered, but it requires no more analysis than the courts have apphied to the problem in the past. In essence, our approach requires that the labor exemption and antitrust questions be answered separately, and that resolution of the foriner question turn exclusively on labor law principles, while resolution of the latter turn exclusively on antitrust law primciples. Under this approach, conduct resulting fronı collective bargaining on mandatory subjects or fronı lawful organizational activity would be immune from 
antitrust attack. ${ }^{202}$ Further, if the court determines that the conduct in question is unprotected by labor law principles or unrelated to mandatory subjects of bargaining, then the court should apply the more flexible rule of reason analysis.

In separating the exemption question from the antitrust hability question and relying exclusively on labor law principles to determine whether the labor exemption should be applied, our approach is an acceptable compromise between the labor and antitrust laws. It protects arguably lawful union conduct and injects some consistency into resolution of the problem. If the market effects of the restraint were removed from consideration, the courts would not have to use a nebulous balancing test in deciding the exemption issue. The courts, however, would still consider the purpose and the gravity of the anticompetitive effects in the rule of reason analysis if the exemption is found inapphicable. In addition to its consistency, our approach would protect the collective bargaining process and would lessen unfairness to employers. Einployers would not be subject to per se antitrust hability where their participation in the restraint was anything less than willing. ${ }^{203}$

\section{A. The Labor Exemption.}

Under our proposed approach to the labor exemption problem, Connell's artificial distinction between the statutory and nonstatutory

202. Logically, conduct that is deemed lawful under the labor laws should be within the labor exemption to the antitrust laws. To be sure, union organizational activity and other concerted efforts not proscribed by Congress should be immune from antitrust scrutiny. With respect to the mandatory-nonmandatory dichotomy, limiting the exemption to mandatory subjects of bargaining insures that those areas of the employer-union relationship involving mandatory subjects of bargaining will not be subject to antitrust regulation. The NLRB has delineated precise guidelines on mandatory bargaining subjects in an effort to promote meaningful negotiation between einployers and their employees' representatives with due regard for the business exigencies attending such negotiation. The antitrust laws should not be invoked to disturb these guidelines, which reflect the experience and expertise of the NLRB.

Those areas of bargaining that are nonmandatory, i.e., that are permissive or illegal, cannot be immune from antitrust scrutiny. Such areas of bargaining often embrace the very type of conduct that the antitrust laws attempt to prohibit. Conduct such as negotiatimg an agreement fixing the prices of employers' goods or the geographical markets for such goods should be subject to prosecution under the antitrust laws, even though the activity may be related to an appropriate, albeit nonmandatory, subject of bargaining. Because the NLRB has specifically found that price fixing and geographical market division are not mandatory subjects of bargaining, the impact of judicial intrusion into this area would be minimal.

203. Our approach is in some ways similar to the approaches suggested by Justice Goldberg in his dissenting opinion in Pennington and his concurring opimion in Jewel Tea and by Professor Handler in his analysis of the labor exemption issue, published prior to the Connell opinion. See Handler, supra note 68, at 238-40. Differences between our approach and Professor Handler's are explained in notes $207 \& 215$ infra. 
exeinptions would be eliminated. As stated earlier, ${ }^{204}$ the distinction is anomalous where applied to the facts of the labor-antitrust cases decided prior to Connell. Further, it gives too broad a scope to the nonstatutory exemption. Indeed, if our approach were characterized under the statutory-nonstatutory dichotomy, it should be considered statutory, since the labor exeinption issue would be determined solely under the Clayton, Norris-LaGuardia, and National Labor Relations Acts.

A second aspect of our approach is that the inarket effects of the union-einployer conduct would be deened irrelevant to the exemption issue. ${ }^{205}$ Accordingly, if the challenged conduct is protected by relevant labor legislation or if the conduct results fronı agreeinent on a mandatory subject of collective bargaining and is free froin other labor policy problems, the labor exemption should be applied and any further analysis should be foreclosed. If neither of these two conditions is met, however, the exeinption should not be apphed, even though the conduct may have followed naturally from, or may have been intimately related to, the protection of legitimate labor concerns.

Our suggested approach to the labor exemption is not without flaws. First, relying exclusively on labor law primciples to decide the exeinption issue nuay result in district courts' usurping or preempting the National Labor Relations Board's role in determining significant or difficult labor law issues. Second, Board and court decisions that classify terms of collective bargaining agreements as either mandatory or nonmandatory do not generally consider the adverse market effects that inay result. Our approach might therefore lead to the subordination of antitrust policies to labor policies. ${ }^{206}$ Finally, one could question the wisdoin of allowing any antitrust analysis of union conduct proscribed by the labor laws, since Congress may have intended the remedies provided by the labor laws to be exclusive. ${ }^{207}$

204. See notes 85-92 supra and accompanying text.

205. This rule would apply unless consideration of such effects was necessary under applicable labor law principIes. See, e.g., Dolly Madison Indus., Inc., I82 N.L.R.B. 1037 (1970) (requiring a finding that no predatory purpose is involved in demanding that a most favored nations clause be included in a collective bargaining agreenent). See generally Comment, Antitrust Law—Most Fa. vored Nation Clause and Labor's Antitrust Exemption, 19 J. PUB. L. 399 (1970).

206. See Meltzer 697, 731-32.

207. See Handler, supra note 68, at 239 n.20 ("Antitrust should have no application to what the Labor Act specifically prohibits; otherwise the forbidden conduct would be subject to dual proceedings and double punishment"). Professor Handler's dual proceeding problem, however, can be alleviated as it was in Consolidated: by requiring charging parties to bring both a scction 301 'claim under the NLRA and either a section 1 or a section 2 claim under the Shernan Act in one suit. His dual punishment problem can be avoided by requiring charging parties to elect their remedies after the substantive labor and antitrust findings are made. $\mathcal{C}$. Consolidated Express, Inc. v. New York Shipping Ass'n, 602 F.2d at 524-25 (complaint seeking Shipping Act reparations 
However valid these criticisms may be, they do not outweigh the benefits of requiring the labor exemption to turn exclusively on labor law principles. Although the National Labor Relations Board preemption problem is particularly troublesome, the Supreme Court has already considered and resolved the issue. In both Jewel Tea and Connell, the Court rejected the argument that the Board has exclusive jurisdiction to determine labor matters where they are presented as collateral issues. ${ }^{208}$ Thus, requiring the courts to apply only labor law principles in deternining the exemption question would probably not aggravate the preemption problem significantly. Further, our approach would prevent incorrect treatment or total disregard of critical labor issues. There would be no chance that the conduct perinitted by the labor laws would be declared unlawful under the antitrust laws. As we have pointed out, this is a distmct possibility under the Court's present exemption test. ${ }^{209}$

There are, admittedly, certam questions of labor law that are difficult to resolve and that may require an extremely sophisticated analysis purely in terins of labor law tenets. The work preservation analysis under sections 8(e) and 8(b)(4), as well as complex issues surrounding the good faith bargaining requirements, certainly epitomizes such problems. Yet the ample National Labor Relations Board precedent in these areas should give the courts sufficient guidance to resolve the difficult labor-related issues. Sections 301 and 303 of the National Labor Relations Act, moreover, confer jurisdiction upon district courts to decide difficult labor issues on first impression. ${ }^{210}$ Indeed, the courts have

filed with Federal Maritime Commission, later voluntarily withdrawn, held not an irrevocable election of remedies and thus no bar to subsequent Clayton Act claim).

208. Connell Constr. Co. v. Plumbers Local 100, 421 U.S. at 626; Local 189, Amalgamated Meat Cutters v. Jewel Tea Co., 381 U.S. at 684-88 (plurahty opinion); id. at 710 n.18 (Goldberg, J., concurring); accord, Mclizer 723.

209. See text accompanying notcs 141-49 supra. Recently, the Nimth Circuit considered the applicability of labor's exemption from the antitrust laws by relying almost exclusively on traditional labor law principles. In Granddad Bread v. Continental Baking Co., 612 F.2d 1105 (9th Cir. 1980), the court ruled that a clause contained in a collective bargaming agreement, restricting the signatory bakers from allowing anyone other than union members to pick up and dehver the bakers' produets, was immune from antitrust attack. The court reasoned that since this clause was related to job preservation and simce the signatory bakers had the right to control the methods of delivery, the umion's conduct was not prohibited secondary activity, which could be subject to the antitrust laws. Id. at 1110 .

Note that after making this ruling, however, the court stated that there was no evidence showmg that the union and signatory bakers "had either entered imto [the agreement] or used it to control the wholesale bread market or to mjure competitors." Id. Thus, although the court disposed of the exemption issue facilely on labor law grounds, it was still nnable to rule on this question without referring unnecessarily to the absence of market effects, which the Connell "follow naturally" test unfortunately requires.

210. 29 U.S.C. $\S \S 185,187$ (1976). 
set landmark precedent, significantly affecting employer-employee relations, without the guidance of National Labor Relations Board case law. ${ }^{211}$ In the event that novel or complex labor law issues are raised $\mathrm{m}$ a particular case, however, the district courts may avail themselves of devices such as references to the Board ${ }^{212}$ or requests that the Board participate as an amicus curiae. ${ }^{213}$

Second, as a general rule the National Labor Relations Board and the courts do not take antitrust policies into account in determining whether any given subject of bargaining is mandatory. As a consequence, if mandatory subjects under the National Labor Relations Act were held totally exempt from the Sherman Act, antitrust policies might in some ways be subordmated to labor law pohcies. ${ }^{214}$ Some form of subordmation, however, is inevitable in reconciling the antitrust and labor laws, and elevatimg mandatory subjects of collective bargaining above the Sherman Act would not be contrary to national interests as a whole, especially where failure to bargam in good faith over such subjects is expressly prohibited by the National Labor Relations Act. Indeed, regardless of any subordmation of antitrust policy, it is paradoxical for unions and employers to be subject to injunctions, treble damages, and possibly even criminal prosecution under the antitrust laws for reaching agreement on employment terms that are mandatory subjects of collective bargaining under the labor laws. ${ }^{215}$

Fimally, any criticisin agamst allowing an antitrust charge to proceed after the union conduct has been held to violate the labor laws is

211. See e.g., Boys Markets, Inc. v. Retail Clerks Union, 398 U.S. 235 (1970).

212. Cf. Tenneco Oil Co. v. Federal Energy Regulatory Comm'n, 580 F.2d 722, 724 (5th Cir. 1978) (decision on appeal of dismissal of petition for declaratory retief withheld pending decision by Federal Energy Regulatory Commission in related admimistrative proceeding).

213. See, e.g., Burco, Inc. v. Whitworth, 81 F.2d 721 (4th Cir.), cert. denied, 297 U.S. 724 (1936); Alexander v. Hall, 64 F.R.D. 152 (D.S.C. 1974); Hubert v. Saucier, 347 F. Supp. 152, 154 (N.D. Ga. 1972). See generally 3B Moore's Federal PRACTice $\llbracket$ 24.02, at 33-34 \& n.9 (2d ed. 1979).

214. See Meltzer 698-99, 734.

215. Accord, Cox, supra note 2, at 271. See also St. Antome, supra note 2, at 614.

Under Professor Handler's approach, nonmandatory subjects of collective bargaining could still be exempted by expanding the exemption on a case-by-case basis. See Handler, supra note 68, at 239 n.20. We disagree with this expansion process for three reasons. First, there is no significant labor policy to be protected by including nonmandatory subjects within the labor exemption. Employers and unions may resist demands for including nonmandatory subjects in a collective bargaining agreement without violating the NLRA, but they inay not do so as to mandatory subjects. Second, any case-by-case analysis of the labor exemption for nonmandatory subjects would most likely lead to some form of balancing test, such as weighing competitivc harm against union interests. A balancing test ought to be avoided for the reasons explained above. Finally, the types of subjects that usually fall within the nonmandatory category, such as restrictions on the way an employer does busimess, are precisely the types of restraints nost likely to have substantial anticompetitive effects that cannot be tolerated nnder antitrust policies. 
refutable. Unions have been subject to the Sherman Act since its enactment, and the Court in Connell rejected the argument that labor law remedies are exclusive.216 Our suggested approach, moreover, is not limited solely to secondary union conduct, which is subject to thirdparty remedial provisions under the National Labor Relations Act, ${ }^{217}$ but extends to all forms of union conduct, including anticompetitive provisions contained in collective bargaining agreements. As a matter of consistency, therefore, secondary activities should not be treated any differently from other forms of union conduct under the antitrust laws. Indeed, the treble-damage provision of the Sherman Act could act as a stronger deterrent to curb unlawful secondary conduct, thus promoting national labor policy. ${ }^{218}$

Applying our suggested approach to the Supreme Court cases that have involved the labor exemption issue would generally lead to the same results reached by the Court. The unions' conduct in both Connell and Allen Bradley would be nonexempt because of the unlawful hot-cargo provisions involved in those cases. Similarly, the union conduct considered in Carroll would be exempt because the restraint in that case involved wages, a mandatory subject of collective bargaining. Although the topic of wages was involved in Pennington, the United Mine Workers' activities would still be nonexempt under our suggested analysis. The union's refusal to bargain unit-by-unit was a violation of labor pohicy, ${ }^{219}$ so that the exemption for conduct related to mandatory subjects would not be available under our approach. Our analysis would, of course, differ from the Pennington Court's: the exemption would not turn on the direct and immediate restraint in the product market or on the alleged conspiracy.

The only case in which our analysis might produce a contrary result is Jewel Tea. In our view, the grocery stores' hours of operation examined in that case could not be considered a mandatory subject of bargaming, despite the fiction created by the Court to tie those hours to the butchers' working hours under the "intmiately related" test. ${ }^{220}$ The union's conduct in Jewel Tea, therefore, would be nonexempt under our suggested rule. Nevertheless, the second element of our suggested

216. 421 U.S. at 634.

217. 29 U.S.C. $\S 187$ (1976).

218. There is a valid criticism that Congress never intended the antitrust laws to apply to secondary union conduct, especially in light of the enactment of section 303 of the National Labor Relations Act. However valid that criticisin may be, the Court in Connell specifically rejected the notion that an affected party's remedies were limited solely to those provided in section 303.421 U.S. at 633-34.

219. 381 U.S. at 666 (plurality opinion).

220. 381 U.S. at 697. 
approach, the rule of reason test, might lead to a finding that the union's conduct did not constitute an unreasonable restraint of trade under the Sherman Act. Indeed, the factors the Jewel Tea Court considered in concluding that the nuarketing hours restriction was intiinately related to legitimate union aims and therefore exeinpt were the saine as those that would be considered under a rule of reason analysis.

\section{B. Rule of Reason.}

As stated earlier, the Supreine Court has never ruled directly on whether the rule of reason or the inore strimgent per se rule of illegality should apply to union-einployer conduct.221 Under our approach the rule of reason is the inore prudent standard for deciding labor-antitrust issues. The rationale behind the per se rule is largely invalid in the context of labor-einployer restraints, and application of that rule would be both inimical to the collective bargaining process and unfair to the parties involved $\mathrm{n} 1$ that process.

The per se rule is premised on the theory that there are certain coininercial practices that are so anticoinpetitive in effect and purpose that they are presumed to be unreasonable without an elaborate inquiry.222 Altlrough the per se premise is unquestionably valid in challenges to commercial practices such as price fixing, group boycotts, and tying agreements, it loses nucli of its force where apphied to restraints imposed by union-employer combinations. That is not to say that such restranits can never be unreasonable within the ineaning of the Sherman Act or that such restraints are procompetitive. To the contrary, virtually every form of union conduct and, indeed, many provisions contained in collective bargaining agreenents are anticompetitive by design. The distinction that inust be drawn, however, is that union objectives are niore often than not directed at the labor narket rather than at the commercial market. The Court noted this difference in Klor's, Inc. v. Broadway-Hale Stores, Inc., ${ }^{223}$ one of the seininal antitrust cases applying the per se rule to condemn group boycotts. Distinguishing Apex Hosiery, the Court observed in Klor's "that the [Slierman] Act is aimed primarily at coinbinations having coinunercial objectives and is applied only to a very limited extent to organizations, like labor unions, which normally have other objectives."224

The facts in Jewel Tea illustrate this distimction. Standing alone and absent any in-depth inquiry, the marketing hours restraint in Jewel

221. See note 181 supra and accompanying text.

222. See, e.g., Northern Pac. Ry. v. United States, 356 U.S. 1, 5 (1958).

223. 359 U.S. 207 (1959).

224. Id. at 213 n.7; see Note, supra note 8, at 831. 
Tea could be viewed as a group boycott imposed by the smaller grocery stores and the unions to force Jewel Tea and the larger stores out of the market of selling meat after 6:00 p.m. The restraint in effect sheltered the smaller concerns from conipeting with the larger firms that could sell meat after 6:00 p.m., without significantly infringing on the unions' work hours and jurisdiction. This view of the niarketing hours restriction formed the gravamen of Jewel Tea's antitrust charge. 225

After considering the history of the unions' collective bargaining negotiations, the purpose of the marketing hours restriction, and the effect of the restriction on the unions' working hours, the Court in Jewel Tea was able to determine that the unions' objectives were related more to preserving working hours (labor market restraint) than to sheltering smaller stores from competition (product market restraint), although the imposition of the restraint had both effects. The point is that without this elaborate inquiry into the unions' aims and the purpose of the restraint, which in fact amounted to a full-scale rule of reason analysis, ${ }^{226}$ the restriction would have been held unlawful.

The labor market-product market distinction is important in other cases involving the labor exemption issue. In Consolidated, for example, there was no question that the International Longshoremen's Association was concerned with its meinbers' job security. Regardless of whether this concern was categorized as work preservation or work acquisition-an issue undoubtedly relevant under the labor laws-the fact is that the union, like the unions in Jewel Tea, imposed the product market restraint to effect a labor market objective. Without a rule of reason analysis, however, that distinction would be overlooked.

Our analysis does not suggest that this distinction automatically separates lawful union-employer conduct froin unlawful union-einployer conduct. Rather, the distinction is made to underscore our view that some union-employer restraints cannot be presumed unreasonable per se. Had it been shown in either Jewel Tea or Consolidated that the unions' objective was exclusively to eliminate competition for the benefit of their employers, then an antitrust charge could have been sustained quite easily. The unions' activities, however, apparently were not directed toward solely anticompetitive goals in either Jewel Tea or Consolidated. Consequently, a different question was presented: whether the unions' concerns over working conditions immunized an otherwise unreasonable restraint of trade. Under the per se approach

225. 381 U.S. at $692-93$.

226. Accord, Handler, supra note 68, at 239-40. 
this issue would be irrelevant because anticompetitive effect and purpose are presumed. ${ }^{227}$

Moreover, if the effect and purpose of a union-employer restraint were ignored through use of the per se rule, employers engaged in the collective bargaining process would be confronted with a Hobson's choice. If they resisted union demands to imcorporate product market restrictions in collective bargaining agreements, then they undoubtedly would run the risk of imcurring union strikes until they agreed to the restriction. If, on the other hand, they agreed to such restrictions rather than face strikes, they could later be confronted with treble-damage actions based on their reluctant acquiescence. ${ }^{228}$

In sum, the rationale and presumptions underlying the per se rule are invalid as apphed to union-employer conduct. As Jewel Tea illustrates, some umon-employer restraints on the product market can be deemed reasonable within the meaning of the Sherman Act once the purpose and the effect of those restramts are exannined. This exannination cannot be made, however, unless a rule of reason analysis is utilized, since the stricter per se rule presumes that both the purpose and the effect of the restraint are unreasonable. Subjectimg the employer to either a strike or the prospect of a treble-damage action under the per se rule would, moreover, be particularly unfair and possibly disruptive of the collective bargaining process. A rule of reason analysis of the umion-employer restraint is required not only to preserve the delicate collective bargaining process, but also to protect employers from being subjected to liability for conduct that they may have had hittle power to resist.

\section{Conclusions}

Perhaps the greatest flaw in the Supreme Court's disposition of labor-antitrust cases is the failure to develop a consistent and intellectually sound principle by which the anticompetitive conduct of unions can be judged. A fair reading of the Court's opinions in this area suggests that it has dealt with the labor exemption on a case-by-case basis, fashioning a slightly different primciple each time it is confronted with the problem. The Court's latest principle, the Connell "follow natu-

227. Admittedly, use of the rule of reason analysis would allow the courts again to test the lawfulness of union conduct under an objectives test, see text accompanying note 20 supra, but apphication of some form of this test is mevitable given the conflicting policies of the antitrust and labor laws. Further, some form of the objectives test is fairer and more prudent than use of the dracomian per se rule, which would not take into account collective bargaining considerations.

228. The Consolidated case represents a classic example of the unfairness in this approach. A Taft-Hartley injunction and federally imposed inediation were required to force the inembers of the New York Shipping Association to agree to the Rules on Containers. 
rally" test, is unsound, for it supplies a dangerous precedent for permitting conduct that is arguably lawful under the labor laws to be the subject of antitrust attack. The test, furtliermore, unwisely blends the substantive antitrust allegations with labor policies, creating a marketeffects analysis that is bereft of guidelines regarding the extent to which anticompetitive effects can be tolerated to accommodate union concerns.

Our suggested approach strikes a balance between the intricate and competing policies of the labor and antitrust laws. It also provides the courts with a uniform standard that protects union concerns and the collective bargaining process, while allowing room for the courts to strike down agreements or conspiracies between unions and eniployers that impair coinpetition in the product markets. In short, our approach injects practical sense into an important and recurring problem that has remained unresolved for too long. 


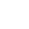

